\title{
The Impasse of Human Rights : A Note on Human Rights, Natural Rights and Continuities in International Law
}

\section{Garcia-Salmones Rovira, Monica}

2019-12-18

Garcia-Salmones Rovira, M 2019 , ' The Impasse of Human Rights : A Note on Human Rights, Natural Rights and Continuities in International Law ' , Journal of the history of pÿinternational law , vol. 21 , no. 4 , pp. 518562 . https://doi.org/10.1163/15718050-12340120

http://hdl.handle.net/10138/322103

https://doi.org/10.1163/15718050-12340120

gnu_lgpl

Downloaded from Helda, University of Helsinki institutional repository.

This is an electronic reprint of the original article.

This reprint may differ from the original in pagination and typographic detail.

Please cite the original version. 


\title{
The Impasse of Human Rights: A Note on Human Rights, Natural Rights and Continuities in International Law
}

Mónica García-Salmones Rovira

\begin{abstract}
Studies on the nature of human rights have reached an impasse largely due to a general resistance to engage with the continuity of ideas and theories drawn from religion, morality and ethics in the history of international law. With the impasse of human rights, the article refers to an epistemological deadlock about what human rights are. Studying the concept of natural rights, it is argued, offers a means of breaking this impasse and, ultimately, easing the current tension between historicism and essentialism in human rights theory. The article concludes that natural rights were means to decide the moral questions posed by the violent redistribution of (material) goods taken to be common by the theoreticians of the expanding European empires. Probing in this manner into natural rights' early uses and embedded theories gives us new tools and fresh approaches to be employed in relation to the challenges posed by contemporary global politics.
\end{abstract}

\section{Introduction}

Studies on the nature of human rights have reached an impasse largely due to a general resistance to engage with the continuity of ideas and theories drawn from religion, morality and ethics in the history of international law. In using the word 'impasse', I refer to an epistemological deadlock about what human rights are. This article argues that studying the concept of natural rights offers a means of breaking this impasse and, ultimately, easing the current tension between historicism and essentialism in human rights theory. I conclude that probing natural rights' early uses and embedded theories provides new tools and fresh approaches that may be employed in order better to understand human rights as they are now. 
Natural rights were a formidable invention. Shaped by discourse among theologians of the

thirteenth century, they served as durable tools for dealing with the thorniest questions of politics,

theology, morality and international legal theory for several centuries. ${ }^{1}$ The morality of property

rights and the political realm for individuals outside the power and control of princes and prelates

are two of the early uses of the concept. ${ }^{2}$ Later, during the sixteenth and seventeenth centuries,

natural rights were decisive in the expansion of Europe and in the expansion of the discipline of

international law as it was understood at least until the twentieth century. From these eight centuries

of history the article selects the period during which the European empires underwent enlargement

\footnotetext{
${ }^{1}$ It is well established that natural rights originated in late medieval theology, which described a right as a licit power and dominion as a human power, both being moral qualities of the individual. It is not possible to survey the relevant literature in the space available here, but for discussion of a few of the most important authors, see the following authors and works: Villey, Michel. 'Les Origines de La Notion Du Droit Subjectif', in Leçons d'histoire de La Philosophie Du Droit (Paris: Dalloz, 1962); Villey, Michel. 'La Genèse du droit subjectif chez Guillaume d'Occam'. Archives de Philosophie du Droit, Le droit subjectif en question 9 (1964), 97-127; Tuck Richard. Natural Rights Theories: Their Origin and Development (Cambridge University Press, 1979), which points rather to a period later than the thirteenth century, by reference to the thought of Jean Gerson (1362-1429); Brett essentially agrees with Villey: Brett, Annabel S. Liberty, Right and Nature: Individual Rights in Later Scholastic Thought (Cambridge: Cambridge University Press, 1997); Finnis, John. Natural Law and Natural Rights (Oxford: Oxford University Press, 2011), hints at the historical fact; as the study of human beings' natural right of subsistence in relation to property rights by thirteenth century theologians, in Mäkinen, Virpi. Property Rights in the Late Medieval Discussion on Franciscan Poverty (Leuven: Peeters, 2001). Tierney rather thought that it was twelfth century canon lawyers who started to refer to natural rights without using that term: Tierney, Brian. The Idea of Natural Rights: Studies on Natural Rights, Natural Law, and Church Law 1150-1625 (Grand Rapids, Michigan/ Cambridge, UK: William B. Erdmans Publishing Company, 2001). Landau did not recognise natural rights in canon lawyers' texts, because he regarded the subjective rights abundant in the sources as being only a reflex of a worldly order, Landau, Peter 'Reflexionen über Grundrechte der Person in der Geschichte des kanonischen Rechts', in Theologia et Jus Canonicum, Festgabe für Heribert Heinemann zur Vollendung Seines 70. Lebenjahres, ed. Heinrich J.F. Reinhardt (Essen: Ludgerus Verlag, 1995), 517532. Despite his theory, Tierney fundamentally agrees with Villey in respect of the importance of the notion of individual powers as employed by William of Ockham. Since Ockham employed the theology and language of rights of the late thirteenth century, I prefer that date. Tierney, Brian. 'Review Article - Medieval Rights and Powers: On a Recent Interpretation', History of Political Thought 21, no. 2 (2000), 327-338. This is a review of Kriechbaum Maximiliane. Actio, ius, und dominium in den Rechtslehren des 13. und 14. Jahrhundert (Ebelsbach: Aktiv Druck, 1996). Kriechbaum tries to avoid a political ('ideological') reading of the legists in favour of interpreting the lawyers seeking practical solutions. In the middle of the last century Leo Strauss made a powerful case to the effect that Hobbes was the 'founder of the specifically modern law doctrine'. Strauss, Leo. Natural Rights and History (Chicago: University of Chicago Press, 1971). In this vein, a good attempt - though ultimately unpersuasive with a view to the sources - to reject Villey's, Tuck's and Tierney's earlier work and their theory that natural rights originated in the Middle Ages, and instead locating its origins in the work of Thomas Hobbes, can be found in Fortin, L. Ernest. 'On the Presumed Medieval Origin of Individual Rights', in Classical Christianity and the Political Order: Reflections on the Theologico-Political Problem, ed. Brian J. Benestad, (Lanham, Boulder, New York, London: Rowman \& Littlefield Publishers, Inc., 1996), 55-79. I have not found an author who argues convincingly that there were natural rights in this modern sense before the Middle Ages. A successful explanation in the opposite sense, which in a word states that there were no inalienable rights for humanity in Antiquity, but only for the Romans, can be found in Giltaj, Jacob and Kaius Tuori. 'Human Rights in Antiquity? Revisiting Anachronism and Roman Law', in Revisiting the Origins of Human Rights eds. Pamela Slotte and Miia Halme-Tuomisaari (Cambridge: Cambridge University Press, 2015), 39-63.

${ }^{2}$ For the former, see Mäkinen, Property Rights in the Late Medieval Discussions on Franciscan Poverty 2001 (n.1); the latter can be found in Tuck, Natural Rights Theories 1979 (n. 1).
} 
(during the sixteenth and seventeenth centuries) and focuses in particular on the role played by natural rights in that process and the manner in which natural rights acquired new substance, from which international law emerged as a product.

A review of the literature on the nature of human rights is first presented. There are two reasons for this. It shows the need for a larger historical framework while at the same time facilitating a shift from the arena of human rights, which is well known to international lawyers, towards the less wellknown territory of natural rights. The analysis describes the impasse in human rights literature mentioned above and suggests that it is hardly possible to describe the nature of human rights while eschewing a cluster of ideas that is often labelled as 'natural law'. Natural law, it is argued, is a complex phenomenon that requires further research. ${ }^{3}$ No better example can be found to illustrate this idea than Hugo Grotius's work. Inspired mainly by scholastic literature, canon and civil lawyers and theologians, Grotius famously wrote that natural rights were a 'moral faculty'. ${ }^{4}$ But then, as Peter Haggenmacher has demonstrated, Grotius's work on international law 'contains only one set of causes of war' that in the main 'coincide with a general system of subjective rights' ${ }^{5}$ In the Grotian tradition, natural rights are well embedded in the laws of war as causes of war. Certainly, they are not particularly abstract or harmless notions. A historical and political study complementing the abstract notions of moral philosophy is needed to make sense of the amphibious character of natural rights. This article suggests that by delving into continuities of ideas and theories of religion, morality and ethics in and across the history and theory of international law, avenues may be also open to develop new methods by which to grasp more effectively the nature of human rights. Both classic authors and the latest literature within the field of the theory and history of international law support this approach

\footnotetext{
${ }^{3}$ For a convincing argument along these lines, see recently Edelstein, Dan. 'Is There a "Modern” Natural Law Theory? Notes on the History of Human Rights'. Humanity 7 (2016), 345-364.

${ }^{4}$ Grotius, Hugo and Richard Tuck (ed.). The Rights of War and Peace (Indianapolis: Liberty Fund, 2005).

${ }^{5}$ Haggenmacher, Peter. Grotius et La Doctrine de la Guerre Juste (Genève: Graduate Institute Publications, 1983).
} 
of continuities. ${ }^{6}$ In respect of natural rights, the implication is that the manner in which the political history of rights is conceived needs revision.

The first part of the text argues that natural rights and human rights share an elusive relationship with morality, religion and the ethical good. Both concepts display an ambiguous nature that is partly secular and partly religious, between tradition and progress. Without rushing to judgment as to particular continuities (or breaks) between natural and human rights, the article highlights this type of metaphysical or cosmological continuity in international law between both types of rights. It argues that while many of the accounts of human rights given in scholarship are, as pieces of a puzzle, valuable and in a sense necessary, they are also consistently fragmentary. ${ }^{7}$

The article proceeds to break the impasse in its second part and does so with a focus on natural rights. The ambiguous nature of natural rights is thus exposed and explained. The text goes on to show how natural rights became a morality of sorts that was increasingly used in place of moral reasoning in respect of practical action. A novelty of the theory is that this morality of natural rights glossed over and substituted moral decisions based on personal conscience. Furthermore, the distribution of the materiality or space of the world appears to be the crucial element at stake in respect of this new approach. Authors seemed to be concerned with producing the distribution of that space on the basis of equality, as in a framework of distributive justice, while natural rights helped to produce claims against other individuals, as in a framework of commutative justice. This article argues that something

\footnotetext{
${ }^{6}$ See Orford, Anne. 'International Law and the Limits of History', in The Law of International Lawyers: Reading Martti Koskenniemi, eds. Werner, Wouter, Alexis Galán and Marieke de Hoon, (Cambridge: Cambridge University Press, 2015), 297-320, especially 311; and Koskenniemi, Martti. 'Vitoria and Us: Thoughts on Critical Histories of International Law'. Rechtsgeschichte - Legal History 22 (2014), 119-138. Among historians, the text that is closest to the method proposed here is perhaps Edelstein Dan. The Terror of Natural Right: Republicanism, the Cult of Nature, and the French Revolution (Chicago: University of Chicago Press, 2009).

${ }^{7}$ For instance, Gearty provides a temporal progression of meanings in the concept of human rights. First a negative meaning is attributed to them, until the last positive one of 'thirst for justice' is gained, which shows human rights becoming ethical, although how that happens is left unexplained. See Gearty, Conor. 'Human Rights: The Necessary Quest for Foundations', in Human Rights Futures, eds. Stephen Hopgood, Jack Snyder and Leslie Vinjamuri, (Cambridge: Cambridge University Press, 2017), 21-38, 38.
} 
new was produced from this combination of elements, (the absence of moral decision, distributive and commutative justice) and that the only way to make sense of natural rights is to describe them as a new form of moral philosophy that was developed in the Middle Ages and later employed contextually with a purpose.

Although this article seeks to shed light on historical processes of European expansion, it is methodological in nature and also aims to explain the epistemological process of the naturalisation of conquest through which that expansion was undertaken. ${ }^{8}$ In the wake of public challenge of the actions demanded by European expansion, theologians, jurists and philosophers regarded these activities as good because they were taken to belong to a cosmology of nature in which human beings acted. A parallel historical and theoretical study of Francisco de Vitoria's Relectio De Indis, Hugo Grotius's De Iure Praedae and John Locke's Two Treatises of Government forms the substance of this section. These oft-discussed scholars have been chosen because they are probably the most influential writers on the issue at hand and because they represent the progressive development of natural rights in ius gentium through theology, jurisprudence and philosophy. The analysis shows the continuity of the concept of natural rights across the different confessions and empires to which these authors belonged and onto the political project that natural rights contributed to advancing during that period. That project appears to have been that of securing trade routes and of carrying out conquest in such a way as not to disturb the consciences of modern Europeans. The background theme of this article is to suggest that one of the central tasks in the development of a theory of rights in the future of international law is to understand politically and situate historically the relationship between human rights and conscience.

\footnotetext{
${ }^{8}$ Rather than aiming at putting forward 'another great narrative' that assumes 'a totalizing "Western legal discourse", a criticism made in Cavallar, Georg. 'Vitoria, Grotius, Pufendorf, Wolff and Vattel: Accomplices of European Colonialism and Exploitation of True Cosmopolitans?'. Journal of the History of International Law 10 (2008), 181$210,207$.
} 


\section{Human Rights and Natural Rights: Between Tradition and Progress}

\subsection{Mapping out the impasse}

The following review divides theoretical studies about human rights into three disciplines: history, law and philosophy. It does not aim to be exhaustive but seeks to be comprehensive about the types of questions that are answered or left unaddressed. In the burgeoning literature on the history of human rights, questions about their foundation or moral nature are mostly substituted by a contextualism of sorts that describes the political principles behind certain historical practices. The practice of human rights is also represented by lawyers, who concentrate on questions of jurisdiction, regime conflict and legal sources and do not, for the most part, question or engage with theoretical issues of foundation, nature or morality. Philosophers of human rights invest serious efforts in describing what human rights are and in devising a theory of human rights, but gloss over the historical, practical or political implications of that theory. ${ }^{9}$ To put the point at its crudest: historians and lawyers tend to engage in practice without theory, while philosophers tend to trust in theory as the sole guide of practice; and both these tendencies obscure, in many ways, the epistemological and empirical questions raised by human rights. The most remarkable features of all the different aspects of the vast human rights literature is lack of clarity concerning the secular and religious features that it variously exhibits, the choice as to which appears to be informed by political preferences on the part of the authors involved, and the puzzlement of the division between the international law of human rights and current practice. ${ }^{10}$

\footnotetext{
${ }^{9}$ Gozzi, Gustavo. Rights and Civilizations: A History and Philosophy of International Law, Filippo Valente trans. (Cambridge: Cambridge University Press, 2019) is an exception to this trend.

${ }^{10}$ With regard to practice, see, for instance, Shestack, Jerome J., 'The Philosophic Foundations of Human Rights'. Human Rights Quarterly 20 (1998) 201-34, which is otherwise a very helpful review of the possible foundations of human rights.
} 
Lynn Hunt, Samuel Moyn, Stephan Ludwig Hoffmann and other authors have studied the phenomenon of human rights from a historical perspective, addressing such questions as what these rights represent and who chooses to argue for or against them. In The Last Utopia: Human Rights in History, Moyn successfully argues that human rights in the West 'in their current sense' arose in the 1970s from the ashes of the process of decolonisation. The Last Utopia describes human rights as recent and contingent. ${ }^{11}$ In an article entitled 'Human Rights and History' (summer 2016) StefanLudwig Hoffmann linked the contemporary characterisation of human rights as 'individual, pre-state and concerned primarily with distant suffering' with the 'ethical turn' of the 1990s towards political philosophy, sociology, law and politics. Accordingly, Hoffmann calls, in the same article, for 'the history of human rights' to be expanded 'to include a moral history of the century after the Enlightenment'. ${ }^{12}$ Lynn Hunt's Inventing Human Rights: A History also engages with the human concerns that human rights are designed to address. ${ }^{13}$ The appearance of a new emotional regime and an imagined empathy with the suffering of our fellow human beings is, for Hunt, the reason for the unfolding of human rights during the late eighteenth century.

The combination of the historical study with an anthropological approach makes these two latter works rare projects within the field of human rights research. Hoffmann's proposal that human rights can legitimately be studied as emerging within the moral disciplines is attractive and accurate. And yet his and Hunt's slightly too safe focus on 'distant suffering' seems to be the beginning rather than the end of the enquiry. On the other hand, The Last Utopia places the notion of human rights in a historical context. The aim of so doing appears to be to settle the question of what current human rights comprise and to project that current legal concept into the past. In this mood the claim that that thing did not exist before is unsurprising. While the endeavour is historically enlightening, it leaves

\footnotetext{
${ }^{11}$ Moyn, Samuel. The Last Utopia: Human Rights in History (Cambridge: Harvard University Press, 2012 ), 117.

${ }^{12}$ Hoffmann, Stefan-Ludwig. 'Human Rights and History'. Past and Present, 232 (2016), 1-32, 30.

${ }^{13}$ Hunt, Lynn. Inventing Human Rights: A History (New York and London: W.W. Norton \& Company, 2008).
} 
the reader with a certain sense of disappointment. Surely, the study of a notion that is so intimately connected with human agency and the morality of the human being ought to encompass that aspect. ${ }^{14}$

Despite this critique, arguably historical studies have achieved greater penetration into the relevant issues than doctrinal works on human rights have managed. Many of those who have studied human rights as a legal phenomenon have come up against the difficulty of not being able to explain clearly what human rights are. The number of studies has increased exponentially over the last thirty years or so. ${ }^{15}$ Those engaged in doctrinal work appear to have given up the struggle for meaning and have instead deployed a manifesto of agnosticism. Thus, one finds candid expressions of 'an evasion of theory', and a general standpoint of just 'assuming' that there are human rights. ${ }^{16}$

It is not a question of singling out this or that text, since this is a general feature of lawyers' work. The standpoint presented by an absence either of theory or of answers to the question of the nature of human rights is not usually offered as the ultimate word, or as a means of protecting one's doctrinal discipline, but as an impasse. ${ }^{17}$ Whatever philosophical orientation one may have, the risk involved in agnosticism looms large, in particular when contemporary politics and practice oscillate between

\footnotetext{
${ }^{14}$ See also Aust, Helmut Philipp. “"The System Only Dreams in Total Darkness”: The Future of Human Rights in the Light of Algorithmic Authority'. German Yearbook of International Law 60 (2017), 71-90. Moyn's recent book Not Enough: Human Rights in an Unequal World, comments on the type of critique levelled at The Last Utopia. He writes that he remains 'unrepentant' concerning his 'emphases'. But the new book is written in a new style, which is more normative and philosophical. Moyn, Samuel. Not Enough: Human Rights in an Unequal World (Cambridge: Harvard University Press, 2018), x. Taking a new approach to the topic, it is interestingly concerned with redistribution, which, as we shall see, is a typical feature of natural rights.

${ }^{15}$ A useful review of many of these attempts can be found in Malcolm, Noel. Human Rights and Political Wrongs: A New Approach to Human Rights Law (London: Policy Exchange, 2017).

${ }^{16}$ Donnelly, Jack and Daniel J. Whelan. International Human Rights (New York: Westview Press, 2018), 24; Alston, Philip and Ryan Goodman. International Human Rights (Oxford: Oxford University Press, 2013). International Human Rights Law stands out in its attempt to overcome the impasse. More about this follows below with a comment on Samantha Besson's work. See also Moeckli, Daniel, Sangeeta Shah, Sandesh Sivakumaran and David Harris, eds. International Human Rights Law (Oxford: Oxford University Press, 2014).

${ }^{17}$ On the protection of one's discipline, see Korhonen, Outi. 'Within and Beyond Interdisciplinarity in International Law and Human Rights'. European Journal of International Law 28 (2017), 625-648.
} 
exposing both the frailty and the power of human rights. ${ }^{18}$ With regard to the latter, Samantha Besson and Noel Malcolm have also stressed the power and legal apparatus with which human rights are endowed, internationally and domestically, and their ambitions for the contemporary world, which make the agnostic position of international lawyers insufficiently robust, if not dangerous. ${ }^{19}$

It is in philosophy where the conception of human rights as natural moral rights is openly advocated. While they tend to conceive the matter in abstraction, it is now primarily philosophers who enquire into the nature of human rights. John Tasioulas's orthodox take is arguably the best approach available on that front. He writes as follows:

'O[rthodoxy] constitutes one historically pertinent sense in which human rights are natural moral rights. They are rights discoverable primarily through the working of ordinary 'natural' and moral reasoning' ${ }^{20}$

In what is perhaps a response to Tasioulas, Noel Malcolm recently argued that 'the nature' of human rights is 'essentially political' ${ }^{21}$ Whether or not one agrees with this statement, it certainly leaves us, again, in an impasse. Is this everything one can know about human rights? Another natural lawyer,

\footnotetext{
${ }^{18}$ Recent studies pointing to both features through different approaches are the insightful ethnographic study by HalmeTuomisaari Miia. 'Methodologically Blonde at the UN in a Tactical Quest for Inclusion'. Social Anthropology/ Anthropologie Sociale 26 (2018), 456-70, and the special issue of Law and Contemporary Problems with a plea for collaboration between fields Loeffler, James and Mila Versteeg. 'Foreword: The Future of Human Rights Scholarship'. Law and Contemporary Problems 81 (2018) i-xi.

${ }^{19}$ Malcolm, Human Rights and Political Wrongs 2017 (n. 15), 103; Besson, Samantha. 'Legal Human Rights Theory'. In A Companion to Applied Philosophy eds. Kasper Lippert-Rasmussen, Kimberley Brownlee and David Coady (London: Blackwell Wiley, 2016), 328-341, 328. See also Conor Gearty, who makes a slightly different point as to embracing the complexity of human rights: 'Human rights need this kind of frank engagement if they are to move to a new level of seriousness, both intellectually and in terms of practice' Gearty, Conor. 'Afterword'. Revisiting the Origins of Human Rights 2015 (note 1), 381-388, at 387.

${ }^{20}$ Tasioulas, John. 'On the Nature of Human Rights', in The Philosophy of Human Rights: Contemporary Controversies, eds. Gerhard Ernst and Jan Christoph Heilinger, (Berlin, Boston: De Gruyter, 2012), 17-59, $26-7$ (italics by Tasioulas).

21 '[T]he concept of human rights has an essentially political nature. It also has an essentially political history'. See Malcolm, Human Rights and Political Wrongs 2017 (n. 15), 130.
} 
Carl Wellman, refers his attempt of grounding human rights in natural rights' theory to Wesley Newcomb Hohfeld's Fundamental Legal Conceptions. ${ }^{22}$ For Hohfeld, the historical perspective enters into the equation again. The most superficial study of the Hohfeldian language of 'rights', 'liberties', 'privileges', 'powers', 'immunities' and 'dominion' makes patently obvious its resemblance to the terminological dissections of the morality of natural rights espoused by the theologians of the Middle Ages. ${ }^{23}$ Among Hohfeld's direct sources, nineteenth and early twentieth century Anglo-Saxon jurisprudence and North American property rights literature stand out. They were in turn inspired by Civilians of the Middle Ages. ${ }^{24}$

Among philosophers, Samantha Besson appears to be the most original and is more interested in developing an autonomous theory of the nature of human rights. She 'wants to bridge the gap' between philosophers and lawyers or, in other words, the gap between real practice and lack of theory ${ }^{25}$ For Besson the deeper structure of human rights is formed by both natural moral rights and 'conventional moral rights', as she calls them. In terms of the history of natural rights, both types are natural rights. The example she gives of a conventional moral right is property, one of the most typical natural rights. Besson also refers to the equalising effect of human rights, another core feature of natural rights. Her commitment to universal legal human rights shows the positive

\footnotetext{
${ }^{22}$ Hohfeld, Wesley Newcomb. 'Fundamental Legal Conceptions as Applied in Judicial Reasoning'. Yale Law Journal 26 (1917), 710-770.

${ }^{23}$ Hohfeld, 'Fundamental Legal Conceptions', 1917 (n. 22), 746; Wellman, Carl. The Moral Dimension of Human Rights (Oxford University Press, 2010), 23. See generally on this topic the work by Michael H. Hoeflich, e.g. Hoeflich, M. H. 'Roman and Civil Law in American Legal Education and Research Prior to 1930: A Preliminary Survey'. University of Illinois Law Review (1984), 717-737. For a classic review of the theologians' language, which also mentions Hohfeld, see Brett, Liberty, Right and Nature 1997 (n. 1); Reid Jr., Charles J.. 'The Canonistic Contribution to the Western Rights Tradition: An Historical Inquiry'. Boston College Law Review 33 (1991), 37-92. The notion of 'powers' and 'rights' are often interchangeable in the sources. Thus, with a historical perspective explaining human rights as arising 'from the state's assumption of sovereign powers', seems to produce a circular reasoning. It might be, however, an accurate description of a circular historical process. See Criddle Evan J., Evan Fox-Decent. Fiduciaries of Humanity: How International Law Constitutes Authority (Oxford: Oxford University Press, 2016) 131.

${ }^{24}$ Hohfeld, 'Fundamental Legal Conceptions' 1917 (n. 22), 729.

${ }^{25}$ See Besson, 'Legal Human Rights Theory' 2016 (n. 19), 335; Besson, Samantha. 'Justifications' in International Human Rights Law, (note 16) 34-53; Besson, Samantha, 'International Human Rights Law and Mirrors'. ESIL Reflections 7 (2018) 16 April 2018, http://www.esil-sedi.eu/node/2109, 4-5.
} 
contribution to international law that studies of natural rights can provide. A different standpoint is taken by Gozzi, who writes that "human rights are not "natural rights"' but 'an imperative that flows from the legal recognition of human dignity'. When attempting to circumvent the connections between 'dignity' and 'natural rights', however, Gozzi rests on the Declarations of Rights proclaimed in the American and French Revolutions, which would appear to entail a return to the concept of natural rights. ${ }^{26}$

Rather than simply assuming that natural rights exist, as philosophers often do, the proposal of this article is to study them and to initiate a conversation concerning studies focused on natural rights conducted in other disciplines.

\subsection{Natural rights in the twentieth century}

I hope that the reasons for the impasse are now clear. A separation of history, practice and theory repeats, with few attempts to unite each of the elements. On the one hand, the over-contextualisation practised by historians assumes or advocates that the present and the future share no epistemological, political and moral ground. The production of knowledge has to start with a clean slate in every historical enquiry, which does not furnish us with a very fruitful standpoint. On the other hand, the idea of continuity shows that the historical point of view is necessary. It is certain that we live in the present and apply human rights in today's world. But the pure epistemological continuity applied by philosophers neglects the political element of history.

\footnotetext{
${ }^{26}$ Gozzi, Rights and Civilizations 2019 (n. 9); see on declarations and natural rights, Strauss, Natural Rights and History 1971 (n. 1), chapter 6; Hunt, Inventing Human Rights 2008 (n.13), specially chapter 3 and Edelstein, The Terror of Natural Right 2009 (n. 6).
} 
In the recent history of international law, the distinguished lawyer Hersch Lauterpacht approached the question of the nature of human rights in an ambitious manner by suggesting that the transformation of natural rights into human rights had occurred due to the exclusively secular nature of the latter. An Austrian-Galizian-Jewish émigré, the Whewell Professor of International Law at the University of Cambridge from 1938 to 1955, and Judge of the International Court of Justice from 1955 until his death in 1960, Lauterpacht was a rich figure, full of contradictions. He was arguably both a positivist, as a student of the great Hans Kelsen, and a proponent of natural law. In April 1942 he was invited by the American Jewish Committee to write a book on international law and human rights. ${ }^{27}$ Philippe Sands notes that in that book Lauterpacht attempted to shift the axis of the international legal order from focusing on the state to focusing on the citizen. In philosophical terms, Lauterpacht made the case for the recovery of a tradition of natural rights, underlining historical continuity within three stages in the history of international law (natural law, the law of nations, international law) and the inspirational order that natural rights could provide 'as a standard of its approximation to justice'. ${ }^{28}$ Lauterpacht depicted natural rights as an ideal order whose core feature was to be 'a source of progress' and, after paying his respects to the old concept, he proposed his preference for an explanation of human rights as secular individual rights.

\footnotetext{
${ }^{27}$ Sands, Philippe. 'Introduction', in Hersch, Lauterpacht. An International Bill of the Rights of Man (Oxford: Oxford University Press, 2015), viii-xxvii, viii. On Lauterpacht's complexity, see Sands, Philippe, East West Street: On the Origins of Genocide and Crimes Against Humanity (London: Weidenfeld and Nicolson, 2016); for a background history on Lauterpacht's involvement on this see Loeffler James. Rooted Cosmopolitans. Jews and Human Rights in the Twentieth Century (New Haven: Yale University Press, 2018), 85-92; on the complexity of Lauterpacht's theoretical project, see Garcia-Salmones Rovira, Mónica. The Project of Positivism in International Law (Oxford: Oxford University Press, 2013), 349-352. Though an author committed to natural law, the international legal theory of Alfred Verdross was more concerned with a natural law of a community or society of states founded on principles such as 'pacta sunt servanda', 'the dignity of man', 'fundamental rights of states' or 'self-determination'. Verdross Alfred. 'Die Wertgrundlagen des Völkerrechts. Archiv Des Völkerrechts 4 (1953), 129-39; for a comment in this sense from Verdross's work before II World War, see Wehberg Hans. 'Alfred von Verdross: Völkerrecht'. Die Friedens-Warte 37 (1937), 145-49.

${ }^{28}$ Lauterpacht, Hersch, An International Bill of the Rights of Man, with an introduction by Philippe Sands (Oxford: Oxford University Press, 2015). For a comment on this episode that also connects natural rights with 'the professional tradition', see Koskenniemi, Martti. 'Human Rights, Politics and Love'. Mennesker Og Rettigheter 33 (2001), 33-45, $34 ; 40$.
} 
Lauterpacht's proposal is among the most serious theoretical enterprises aimed at providing a foundation for human rights over the past century and it is certainly no surprise that few have dared to follow suit. Moreover, he stood quite alone in his effort to imbue late twentieth century international legal theory with the concept of natural rights. And - albeit with a few exceptions that are now to be found in international economic law - it may ultimately be concluded that natural rights appear to have been forgotten..$^{29}$ To cut a very long story short, nowadays natural rights appear to contemporary international lawyers to be a relic from the European past, belonging to the Middle Ages or relating to Grotius, when people still believed in God. In his bold defence of human rights and sovereignty as the dual foundation of international law, Itamar Mann writes in a straightforward way about this phenomenon: 'unlike Grotius' who lived in a 'normative universe' today we can no longer consider human rights to be 'natural' ${ }^{30}$ Natural rights are considered to have had a role in a historical era that has passed, and perhaps their last radical flourish occurred during the North American revolution. ${ }^{31}$

\subsection{Religion, natural rights and human rights}

It was mentioned at the outset that natural rights originated within a theological intellectual discourse. However, their relationship with religion is complex and unobvious. As it stands, the huge topic of

\footnotetext{
${ }^{29}$ For instance, one of the definitions of carbon rights is that they amount to 'a moral claim to benefit from carbonbased payments', in Creating an Enabling Legal framework for REDD+Investments in Kenya, Baker \& McKenzie \& Cambridge Center for Climate Change Mitigation Research (2014), 20. Available at https://www.4cmr.group.cam.ac.uk/research/projects/reddpluslawproject; Steenmans, Katrien, Jane Marriott and Rosalind Malcolm. 'Commodification of Waste: Legal and Theoretical Approaches to Industrial Symbiosis as Part of a Circular Economy' (2017), University of Oslo Faculty of Law, Research Paper No. 2017, 26. Available at https://www.smart.uio.no/publications/smart-working-paper-series/. For a recent discussion of the recasting of natural rights as the rights of nature, see Carducci, Michele. 'Natura (diritti della)', in Digesto Delle Discipline Pubblicistiche, ed. Rodolfo Sacco, (Torino: Utet, 2017), 486-521.

${ }^{30}$ Mann, Itamar. Humanity at Sea: Maritime Migration and the Foundations of International Law (Cambridge: Cambridge University Press, 2016), 216 (emphasis by Mann).

${ }^{31}$ Paul Kahn shows that natural rights theory and a non-retributive (through non-intervention) God was part of the Founders' project: Kahn, Paul W. 'The Law of Nations at the Origin of American Law', in International Law and Religion: Historical and Contemporary Perspectives, eds. Martti Koskenniemi, Mónica García-Salmones and Paolo Amorosa, (Oxford: Oxford University Press, 2017), 414-32.
} 
natural law and natural rights in the history of international law is still an under-researched area. Lack of clarity and ambiguity notwithstanding, even the toughest opponent of natural rights would not deny that they were pivotal in the political and legal history of the Western tradition. ${ }^{32}$ And yet, many unconscious connections and assumptions surround the invocation or even the mention of natural rights today and, in contrast to Lauterpacht, we feel the need to distance ourselves from a seemingly embarrassing past. ${ }^{33}$

The fascinating thing is that this confusion surrounding the notion of natural rights has tainted the notion of human rights as well. Together with the impasse in the very pro-human rights literature that I have described above, there is also a large body of literature criticising human rights,$^{34}$ and critics often also point to their ambiguous nature and obscure pedigree. On the whole, what seems to be constant is the sense of bewilderment when trying to understand what natural rights and human rights are. How do natural and human rights relate, if at all, to a theory of justice and moral and ethical decision? Admittedly this question is too broad to be answered in the scope of an article, but I propose to start breaking the impasse by dissolving the actual methodological separation and uniting history, theory and practice. And chronologically and logically, the study of natural rights seems to be a meaningful place to start. In the following section, therefore, the curious nature of natural rights is exposed and explained, and its Janus face - simultaneously divine and secular, progressive and conservative and natural and conventional - is revealed.

\footnotetext{
${ }^{32}$ For a similar point and for his comment on the historical research on the matter that '[i] $\mathrm{n}$ this conflicted realm, then, complexity reigns now as king', see Oakley. Francis, Natural Law, Laws of Nature, Natural Rights: Continuity and Discontinuity in the History of Ideas (New York: Continuum, 2005), 88. See also, for its highlighting of relevance, confusion and complexity, the recent study by Koskenniemi, Marti. 'Rights, History, Critique', in Human Rights: Moral or Political?, ed. Adam Etinson (Cambridge: Cambridge University Press, 2018), 41-60, 42.

${ }^{33}$ The feeling of embarrassment is referenced by Moyn, who writes that 'naturalism' has supported 'all manners of horrors over time'. See Moyn, Samuel. 'The Embarrassment of Human Rights'. Texas International Law Journal: The Forum 1 (2015), 1-7, 6. However, even Lauterpacht narrated a history of the 'damnosa hereditas' of natural rights, e.g. the attempts at social reform through legislation made in nineteenth century America, which were hampered through invocation of the natural right to private property, Lauterpacht (n. 28), 36-7.

${ }^{34}$ For a review of critical literature, see Dembour, Marie-Bénédictine. 'Critiques', in International Human Rights Law 2014 (n. 16) 53-74 and Malcolm, Human Rights and Political Wrongs 2017 (n. 15).
} 


\section{Vitoria, Grotius, and Locke on Natural Rights: Naturalising the International}

The sixteenth century Spanish theologian-jurist Francisco de Vitoria, founder of the School of Salamanca, and the seventeenth century Dutch jurist-theologian Hugo Grotius are usually considered the fathers of international law. In the eighteenth century, protestant historiography centred around Hugo Grotius, and in the twentieth century American scholars' new universalism helped to rediscover the teachings of the School of Salamanca, and especially of Vitoria. ${ }^{35}$ Despite the three quarters of a century that lies between Vitoria and Grotius, there are at least six common elements in their understanding of the emerging law of nations. Both postulated certain Roman law norms that could be universally applied and both were pioneers in producing appraisals of the concept of a global community among human beings without a common authority: ${ }^{36}$ the natural society and natural partnership, 'naturalis societatis et comunicationis' in the original Latin text of Vitoria's Relectio de Indis. ${ }^{37}$ Concerning Vitoria's novelty in this regard there is little that may be added to the excellent studies already available. ${ }^{38}$ But perhaps noting that he incorporated the

\footnotetext{
${ }^{35}$ See Tuck, Richard. 'Introduction', in Grotius, Hugo, The Rights of War and Peace, $\mathrm{x}$; Brown Scott, James The Spanish Origin of International Law: Francisco de Vitoria and His Law of Nations (Oxford: Clarendon Press, 1934). See also the comment in Smeltzer, Joshua. 'On the Use and Abuse of Francisco de Vitoria: James Brown Scott and Carl Schmitt'. Journal of the History of International Law 20 (2018), 1-29.

${ }^{36}$ For a useful comment on Vitoria's use of Roman law notions such as ius gentium and dominium and on his understanding of the natural society, see Brett (n. 1), 82, 124-37. For the point that Roman law provides the structure for Grotius' De Iure Praedae, see Straumann, Benjamin. Roman Law in the State of Nature: The Classical Foundations of Hugo Grotius' Natural Law (Cambridge: Cambridge University Press, 2015).

${ }^{37}$ Nys, Ernest (ed.), Pawley Bate, John (trans.), de Vitoria Franciscus, de Indis et de iure belli (New York, London: Oceana Publications, 1917), 257.

${ }^{38}$ Despite his critique, Fernández-Santamaría names, among the contributions of the School of Salamanca to the history of political thought, "the outlook that insisted, in contrast with the growing territorial parochialism which was to dominate Western political thinking, in viewing the society of man not as limited by artificial and impermanent national boundaries but as indivisible one coterminous with the eternal physical frontiers of the inhabited globe itself'. Fernández-Santamaría, J.A. 'Francisco de Vitoria (II)', in The State, War and Peace: Spanish Political Thought in the Renaissance 1516-1559 (London, New York, Melbourne: Cambridge University Press, 1977), 113. The very adoption by Grotius of Vitoria's outlook is a recognition of that contribution. Different variations of the acceptance of Vitoria's novelty appear in Brown Scott, The Spanish Origin of International Law 1934 (n. 35); Schmitt, Carl. Der Nomos der Erde im Völkerrecht des jus publicum Europaeum (Berlin: Duncker \& Humblot, 1974), 72-95; Anghie, Antony. 'Francisco de Vitoria and the Colonial Origins of International Law'. Social \& Legal Studies 5 (1996), 321-36;
} 
Aristotelian society of individuals in communication with one another to the factual Spanish global conquest underlines my point.$^{39}$ Grotius accepted this natural society and enlarged it by means of scriptural arguments. ${ }^{40}$

Christian theology and canon law constituted a third element. A fourth common element - and the reason why these authors are relevant to this discussion - is their foundational employment of natural rights, which Vitoria and Grotius use identically in their natural law projects. The role of natural rights in their arguments is the same, in terms of logic, for both natural lawyers, as shown in the following pages. Apart from natural rights, Vitoria and Grotius have two other big common themes: each deals systematically with the laws of war and each deals with what was the key issue in foreign relations in their eras: the protection of trade routes. For Vitoria, it was trade with the West Indies in America that was of key importance. For Grotius, it was trade with the East Indies in Asia, Ceylon, the Moluccas, Sumatra, China and Japan. Whereas from Vitoria's standpoint the Indians were the threat to a smooth trade-flow, for Grotius the principal danger was rival Portuguese and Spanish traders - i.e. Europeans themselves were the threat. That is not to say that Grotius's warnings did not sometimes extend to non-Europeans and their alliances with Europeans. Rather, the idea indicates the universality of the intellectual enterprise of natural rights.

\footnotetext{
Koskenniemi, Martti. 'Empire and International Law: The Real Spanish Contribution'. The University of Toronto Law Journal 61 (2011), 1-36. Albert the Great thought of a located civilitas and an abstract civilitas of knowledge. Political communication and the transfer of goods for common usage takes place in a located, Aristotelian community. Magni, Alberti and Kübel, Wilhelm (ed.), Super Ethica vol. I (Coloniae: Monasterii Westfalorum in Aedibus Aschendorff, 1968). The end that Dante had in mind for human beings was similar to Albert's: that of the immense potential of knowledge that might be only brought to flourish through the mutual exchange of knowledge within the larger community of humanity itself. To achieve this end Dante needed a universal monarch. Dante, Alighieri. De Monarchia. The 'Oxford Text', ed. Dr E. Moore with an 'Introduction on the Political Theory of Dante' by W. H. V. Reade, (Oxford: Clarendon Press, 1916); Rosier-Catach, Irène. 'Civilitas'. in Mots Médiévaux Offerts à Ruedi Imbach eds. I. Atucha, D. Calma, C. König-Pralong, and I. Zavattero (Porto, Turnhout: Brepols, 2011), 163-75.

${ }^{39}$ Aristotle, The Nicomachean Ethics, translated by David Ross, revised with an introduction by Lesley Brown (Oxford: Oxford University Press, 2009), Book VIII.

${ }^{40}$ Grotii, Hugonis. De Jure Praedae. Comentarius, ed. Gerard Hamaker, Hendrik, (The Hague: Martinum Nijhoff, 2003 (1868)), 21. The foundational source is, however, Aquinas. See Borschberg, Peter. "'De Societate Publica Cum Infidelibus". Ein Frühwerk von Hugo Grotius'. Zeitschrift der Savigny-Stiftung für Rechtsgeschichte 115 (1998), 355393; van Ittersum, Martine Julia. Profit and Principle: Hugo Grotius, Natural Rights and the Rise of Dutch Power in the East Indies (1595-1615) (Leiden, Boston: Brill, 2006), 49-50.
} 
Locke's texts, written in the late seventeenth century, do not appear to have all these elements in common with the Spaniard and the Dutchman, but the manner in which he capitalised upon natural rights in his theory is, again, the same as that of Vitoria and Grotius. The common construction of the concept of natural rights in the three authors is analysed below.

\subsection{Vitoria: ordering communication}

Vitoria was a humanist. ${ }^{41} \mathrm{He}$ has often been praised in the historiography of international law as the protector of the Indians of the newly discovered America, in particular for his Relectio de Indis, a lecture given in 1539 and copied by his students. The main content of Relectio de Indis was the description and arguments concerning which claims of title to the land in America were either unlawful and lawful and as to whether, on the basis of this, the Spanish were entitled to continue their presence and actions there. The theologian has been portrayed as a defender of the Indians, since of the 53 pages of the text - in the Latin edition of the Carnegie Classics of International Law - Vitoria devoted 35 pages to putting forward arguments explaining why the Indians had true dominion (dominium) and analysing the unlawful titles of the conquest. A defence of the Indians flows from this. ${ }^{42}$ The Emperor did not have any form of title over the whole world that he could bestow on the Spanish, and nor did the Pope. To be non-Christian was no impediment for the Indians to be true lords of their territories, and true owners of their goods. Therefore, people could not simply travel to America and despoil them of their gold and other goods. In short, when Spaniards sailed West for the

\footnotetext{
${ }^{41}$ Villanueva Fernández, Juan Manuel. 'Erasmismo o Teología Española Del Siglo XVI?', in Cervantes y las Religiones, eds. Ruth Fine, and Santiago López Navia, (Madrid: Iberoamericana, 2008), 301-326; Pena González, Miguel Anxo. 'La "Escuela de Salamanca": Un intento de delimitación del concepto', in Escuela de Salamanca. Filosofía y humanismo ante el mundo modern, ed. Ángel Poncela González, (Madrid: Editorial Verbum, 2015), 83-130.

42 de Vitoria Francisco. 'On the American Indians', in Vitoria: Political Writings, eds. Anthony Pagden, and Jeremy Lawrance (Cambridge: Cambridge University Press, 1991), 239; de Vitoria, De Indis et de iure belli 1917 (n. 37), 225, $231,232$.
} 
first time, 'to the land of the barbarians, carried with them no right at all to occupy their countries' ${ }^{43}$ The question that Vitoria posed in De Indis had been tirelessly debated before him and in the introduction of the Relectio de Indis he gave his own reasons for participating in the debate. As a question of doubtful conscience, it was for theologians to decide. ${ }^{44}$ They, it was argued, bore the necessary authority. Luciano Pereña considered Vitoria's principal audience to be Francis I, King of France, and Carlos V. The main purpose of his lecture appears to have been to quiet the fears of the former with regard to title, to temper the imperialism of the latter, and also to instruct 'European conscience' at large. ${ }^{45}$

Moreover, in De Indis no reference is made to earlier doctrinal justifications of the Conquista, neither to criticise nor to support them. Instead, and with hindsight this is quite remarkable for a lecture given in the middle of the sixteenth century, together with several contemporary authors, the main sources for Vitoria's resolution of the argument in De Indis stem from the thirteenth and early fourteenth century. The Parisian theologians Thomas Aquinas (1225-1274), Henry of Ghent (1217-1393), Durandus of Saint Pourçain (1275-1234) and Peter Paludanus (1275-1342) had shown that the pope had temporal jurisdiction ordained to the spiritual good - hence the valid grant of overseas territories by Alexander VI to the Spanish and the Portuguese. ${ }^{46}$ With regard to thirteenth century canon lawyers, Vitoria's key source is Pope Innocent IV's commentary (of about 1243) on whether non-Christians can be dispossessed of their territories and their political authority. Innocent IV based his analysis on

\footnotetext{
${ }^{43}$ Vitoria, 'On the American Indians' 1991 (n. 42), 264.

${ }^{44}$ A comment on this argument in García-Salmones Rovira, Mónica. 'The Disorder of Economy? The First Relectio de Indis in a Theological Perspective', in System, Order and International Law: The Early History of International Legal Thought from Machiavelli to Hegel, eds. Stefan Kadelbach, Thomas Kleinlein, and David Roth-Isigkeit (Oxford: Oxford University Pres, 2017), 443-463.

${ }^{45}$ Pereña, Luciano. 'La Escuela de Salamanca y la Duda Indiana', in Ética en la Conquista de América, eds. Demetrio Ramos Pérez et al, (Madrid: Consejo Superior de Investigaciones Científicas, 1984), 291-344, 299-300. For the significance of Vitoria's De Indis for the constitutional programme of the Spanish Empire in relation to conquest, see Pereña, Luciano. 'Proyecto de Reconversión Colonial', in Escuela de Salamanca. Carta Magna de los Indios. Fuentes Constitucionales, 1534-1602, eds. Luciano Pereña and Carlos Baciero (Madrid: Consejo Superior de Investigaciones Científicas, 1988), 3-32.

${ }^{46}$ de Vitoria, De Indis et de iure belli 1917 (n. 37), 242.
} 
an earlier papal decretal by Innocent III, Quod super his (1199), and his short answer was that God has given dominion to all rational creatures, and that to occupy what belonged to others was against natural law. ${ }^{47}$ Vitoria's contribution was to add to the review of masters, the subtle twist of his own humanist and naturalist approach. He stated that the pope had no spiritual jurisdiction over the Indians and couched the entire solution in the language of natural rights. ${ }^{48}$

The turning point in De Indis is where Vitoria describes the status quo and follows that with a discussion of the lawfulness of the Spanish claims over land. He depicted the nature of the relationship between the Spanish and the Indians in a striking manner in the first just title by which he held the Indians 'passed under the rule of the Spaniards':

Amongst all nations it is considered inhuman to treat strangers and travellers badly without some special cause, humane and dutiful to behave hospitably to strangers ... [i] t would not be lawful for the French to prohibit Spaniards from travelling or even living in France, or vice versa, so long as it caused no sort of harm to themselves; therefore, it is not lawful for the barbarians to prohibits the Spaniards from travelling to their territories either. ${ }^{49}$

The utopian bent is in evidence. He imagined the Indians during the Spanish Conquista as equal members of a natural society. Famously, the critical scholar Tony Anghie has written that when the Indians were included in the natural society they became, much to their disadvantage, perpetual

\footnotetext{
${ }^{47}$ Innocent IV. Apparatus in Quinque Libros Decretalium (Frankfurt am Main, 1570), III, 34, 8, 430. For a comment, see Muldoon, James. 'Medieval Canon Law and the Formation of International Law'. Zeitschrift der Savigny-Stiftung für Rechtsgeschichte. Kanonische Abteilung 81 (1995), 64-82.

${ }^{48}$ Vitoria, 'On the American Indians' 1991 (n. 42), 262-263.

${ }^{49}$ Vitoria, 'On the American Indians' 1991 (n. 42), 278.
} 
transgressors of the 'inescapable' laws of that natural partnership. ${ }^{50}$ The first just title for the Spanish is thus the existence of a natural society or natural partnership, a type of ideal order among peoples. At the outset it engenders two natural rights, which - it cannot be sufficiently emphasised - Vitoria the theologian was inventing: ${ }^{51}$

First just title of natural partnership and communication (naturalis societatis et communicationis). My first conclusion on this point will be that the Spaniards have the right to travel and dwell in those countries, so long as they do no harm to the barbarians and cannot be prevented by them from doing so..$^{52}$

Vitoria was thus being creative; first by inventing the 'natural society' and then by stating that there are rights that arise from a natural partnership between peoples. ${ }^{53}$ This wonderful artificiality of nature would become a very productive source for the law of nations, not only in Vitoria's work, but also in that of Grotius, Locke and other authors writing between the sixteenth and eighteenth centuries. ${ }^{54}$ The first consequence of this natural society is the natural right to move freely within the global community.

In a somewhat circuitous statement Vitoria determined that his theory of the natural society was founded on natural reason, which gave natural rights a foundation in secularity. ${ }^{55} \mathrm{~A}$ brief comment

\footnotetext{
${ }^{50}$ Anghie, Anthony. Imperialism, Sovereignty and the Making of International Law (Cambridge University Press, 2004), 21.

${ }^{51}$ See also Pagden, Anthony. 'Human Rights, Natural Rights and Europe's Imperial Legacy'. Political Theory 31 (2003), 171-199, 185 and 197.

${ }^{52}$ Vitoria, 'On the American Indians' 1991 (n. 42), 278.

${ }^{53}$ The novelty is the notion of a natural right to hospitality, not that of hospitality, as it is evident in the classics. See for instance Book I of Virgil, The Aeneid, D. West (trans. and introduction) (London: Penguin Books, 2003).

${ }^{54}$ The expression 'wonderful artificiality of nature' is inspired in that of 'the wonderful artificiality of states' paralleling the important theoretical function that 'nature' is made to perform in the law of nations during this period with that of the states later for international law. See for that expression, Koskenniemi, Martti. 'The Wonderful Artificiality of States'. Proceedings of the ASIL Annual Meeting 88 (1995), 22-29.

${ }_{55}$ Vitoria, 'On the American Indians' 1991 (n. 42), 278.
} 
may be made concerning Vitoria's novel integration of natural rights within ius gentium. De Indis established the Indians' natural right of dominion ('dominium est ius'), which, in the elaborated Vitorian understanding, combining both tradition and modernity, is a 'subjective right' ${ }^{56}$ It also established several natural rights enjoyed by the Spanish, which were, admittedly quite substantial in the context of an imperial conquest and the expansion of a commercial empire. Vitoria mentioned the natural 'right to travel' and 'to dwell' in America, and 'to commerce' (ius negotiandi), which allowed the Spanish to use 'the legal privileges and advantages granted to all travellers', such as 'communication' in 'what is common' among them, such as 'gold' or 'pearls', the right to preach (ius praedicandi) to 'those who voluntary want to listen'. All these rights were accompanied by the eventual sanction 'licitly to wage war in order to obtain their right, if necessary'. ${ }^{57}$ Noting the extraordinary number of rights bestowed on the Spanish allows one to gain a perspective on the political emancipatory value of natural rights at that particular moment and place in European and global history.

Vitoria boldly availed himself of his authority as a theologian. ${ }^{58} \mathrm{He}$ recommended decision-making

\footnotetext{
56 'Vitoria's dominium ... is the (unqualified) subjective right, or better, subjective right simpliciter'. Brett (n. 1), 130; the modernity of Vitoria is perhaps overly accentuated in Deckers, Daniel. Gerechtigkeit und Recht. Eine historischekritische Untersuchung der Gerechtigkeitslehre des Francisco de Vitoria (1483-1546) (Freiburg: Universitätsverlag, 1991). However, by the sixteenth century the notion of subjective natural rights was not a modern concept, since it already formed part of an established theological tradition. Vitoria's commentary on the Secunda Secundae is where he explains his threefold conception of dominion. As is well known, Vitoria adhered to the Thomist tradition of natural law and was also heavily influenced by the parallel natural rights strand developed by Jean Gerson, Conrad Summerhart and others. The third and broader concept of dominion in Vitoria's theory corresponds to moral matters, according to which dominion is a subjective natural right ('dominium est facultas utendi re secundum jura vel leges rationabiliter instituta'). This is the notion that Vitoria employs to establish that those who are irrational cannot have legal rights. Indians were rational, ergo they were true masters. de Vitoria, Francisco. Comentarios a la Secunda Secundae de Santo Tomás, III De justitia, q. 57-66, ed. Vicente Beltrán de Heredia (Apartado 17: Salamanca, 1934), 67.

57 Vitoria, 'On the American Indians' 1991 (n. 42), 279, 282, 284, 286; de Vitoria, De Indis et de iure belli 1917 (n. 37) 260. Even Robert A. Williams's very critical standpoint praises Vitoria on natural rights. See Williams, Robert A. Jr. The American Indian in Western Legal Thought: The Discourse of Conquest (New York: Oxford University Press, 1990), 96-97, 114. In this vein in the recent translation of his book on rights Gustavo Gozzi underscores the innovation of Vitoria in 'recognizing the plurality of sovereign states and the equal rights of peoples (even if Vitoria managed to inconsistently work an exception into this statement of principle, arguing for the legitimacy of the Spanish conquest)'. Gozzi, Rights and Civilizations 2019 (n. 9), 10-11. While also recognising the novelty of Vitoria's work, this article argues that the fact that Vitoria recognised natural rights was not inconsistent with but rather put at the service of the conquest.

${ }^{58}$ García-Salmones, 'The Disorder of Economy? (n. 44).
} 
both on the basis of 'probable reasons' and counting on the 'authority of the wise men'. However, in the long opening section of De Indis justifying the piece, he was adamant that 'in cases of doubt' the wise should be trusted:

'it is not enough in conscience for a man to judge by himself whether his actions are good or bad. In cases of doubt he must rely on the opinion of those authorized to resolve such doubts' ${ }^{59}$

And then, in explaining the legal validity of the Spanish presence in America, he went on to contend that the Spanish had several natural rights that made their actions and even war licit. Vitoria's intervention was judged in various different ways. Interpretations ranged from convincing the doubtful emperor that Spain was no longer entitled to leave America to the Americans, to advocating a more humanist approach to the whole enterprise. There are two items that indicate the complexity of Vitoria's position and which show that he was not merely another pamphleteer. De Indis lacks a commentary on the system of forced labour of natives (encomiendas), which was the main bone of contention in respect of the continuation of the Conquista ${ }^{60}$ In Castile a technical term was coined, 'la duda indiana' (the Indian doubt) that expressed the perplexity of good intentions - imperial grandeur and richness, civilisation, and evangelisation - materialising in terrible deeds.$^{61}$ Secondly, his claim in the conclusion of the text that with or without title and hence with or without actual presence in America, the trade and taxes on it 'would not have to cease' ${ }^{62}$ As I have been arguing, for this author the question of instructing conscience was not just an aesthetical

\footnotetext{
${ }^{59}$ Vitoria, 'On the American Indians' 1991 (n. 42), 236.

${ }^{60}$ However, there are two veiled mentions of the justification of the system of forced labour de Vitoria, De Indis et de iure belli 1917 (n. 37) 232; 267.

${ }^{61}$ Lucena, Manuel. 'Crisis de la conciencia nacional. Las dudas de Carlos V', 163-198; González, Jaime. 'La Junta de Valladolid convocada por el Emperador', 199-228, both in La ética en la Conquista de América, eds. Demetrio Ramos Pérez et al (Madrid: Consejo Superior de Investigaciones Científicas, 1984).

${ }^{62}$ A novel explanation of the contribution to international economic law of the Salamancan theologians highlighting their language of natural private rights can be found in Koskenniemi, Martti. 'Empire and International Law: The Real Spanish Contribution'. University of Toronto Law Journal 61 (2011), 1-36.
} 
or literary tool. Vitoria declared that this was a question of conscience and that it was for the theologians to decide. But then, as Rudolf Schüßler notes, instead of using the rules of doubtful conscience, Vitoria surprisingly went on to employ the rules of just war. ${ }^{63}$

\subsection{Grotius: ordering the execution of rights}

Grotius had been a child prodigy and he produced his first important work on international law, De Iure Praedae (The Law of Prize and Booty), in his early twenties. The context of this piece is well known. In the course of a series of Dutch attempts to breach the Portuguese commercial monopoly in the East Indies, on 25 February 1603 the Dutch captain Jacob van Heemskerck attacked and captured the Portuguese merchantman Santa Catarina in the Strait of Singapore. The prize was a rich one indeed. The auction of the carrack in Amsterdam in the autumn of 1604 realised a sum that has been estimated at more than three million Dutch guilders. Van Heemskerck's employer, an Amsterdam firm of shipowners later incorporated within the United Dutch East India Company or VOC (Verenigde Oost-Indische Compagnie), asked the young jurist Hugo Grotius to defend the justice of the capture and the legitimacy of the prize. Grotius accepted this task and between October 1604 and November 1606 he was employed in writing the tract requested. ${ }^{64}$ As in Vitoria's De Indis the outcome was half apology, half new legal theory and doctrines. De Iure Praedae resulted in a text that would serve later as the archetype for Grotius's much more developed The Rights of War and Peace (1625).

In the introduction to De Iure Praedae Grotius defined his mission in writing an apology for the

\footnotetext{
${ }^{63}$ Schüßler, Rudolf. Moral im Zweifel. Die scholastische Theorie des Entscheidens unter moralischer Unsicherheit v. I (Paderborn: Mentis, 2003), 122 -3, and generally chapter 3.

64 This explanation and more details can be found in van Ittersum, Martine Julia. 'Hugo Grotius in Context: Van Heemskerck's Capture of the "Santa Catarina” and Its Justification in “De Jure Praedae” (1601-1606)'. Asian Journal of Social Science 31 (2003), 511-548; also van Ittersum, Martine Julia. 'Introduction' to Hugo Grotius Commentary on the Law of Prize and Booty (Indianapolis: Liberty Fund, 2006).
} 
capture of the Santa Catarina as a question of instructing conscience. He announced that he would show that what had been done was honourable and that he was discussing the question 'not only for debate as to whether the aforesaid act was right or wrong' but 'since the circumstances remain unchanged, advice must be given as to whether or not the course of action already adopted is expedient for the future' ${ }^{65}$ Years later, when the Dutch defended Mare Liberum from William Wellwod's critique he repeated that he saw that the commerce in the East Indies was vital for 'the safety' of his country and that without arms it could not be maintained. Therefore, he wrote:

'I gave my attention to stirring up the minds of our fellow-countrymen to guard bravely what had been felicitously begun, putting before their eyes the justice and equity of the case itself' ${ }^{66}$

In his elegant nineteenth century essay on De Iure Praedae, Robert Fruin considered that Grotius was mainly addressing the Dutch pacifists among the shareholders of the East India Company. But he also provided a realist reading of some of the 'doubts of conscience' that might have involved mixed motives, in being prompted also by discontent with insufficient profit among shareholders. ${ }^{67}$ Notwithstanding a possible realist reading, the 'limiting' effect of faith and morality among merchants rejecting fighting and pillage seemed to have been real. ${ }^{68}$ Martine Van Ittersum deals extensively with the question of Grotius's audience: there was the real or imagined danger that scruples of conscience would prompt shareholders to withdraw investment, as in fact happened with

\footnotetext{
${ }^{65}$ Grotius, Hugo. Commentary on the Law of Prize and Booty (Indianapolis: Liberty Fund, 2006), ch.1, 18.

${ }^{66}$ Grotius, Hugo. The Free Sea. Translated by Richard Hakluyt with William Wellwod's Critique and Grotius's Reply, ed. David Armitage, (Indianapolis: Liberty Fund, 2004), 60.

${ }^{67}$ Fruin exposed, albeit gently, these mixed motives. See Fruin, Robert. An Unpublished Work of Hugo Grotius's (translated from an 1868 essay in Dutch), in Hugonis Grotii de Jure Praedae, ed. H.C. Hamaker (Clark, New Jersey: The Lawbook Exchange, 2003), 33-34 and generally chapter 3.

${ }^{68}$ Not only by Mennonites merchants, although especially by them. See Sprunger, Mary S. 'The Limits of Faith in a Maritime Empire: Mennonites, Trade and Politics in the Dutch Golden Age', in The Limits of Empire: European Imperial Formations in Early Modern World History. Essays in Honor of Geoffrey Parker, eds. Tonio Andrade and William Reger, (London and New York: Routledge, 2016), 59-78, 63.
} 
the troublesome Pieter Lijntgens. ${ }^{69}$ Van Ittersum and also Borschberg extend Grotius' target to encompass the government itself, the Dutch States General and the provincial Estates, so that they would help the company with the costs of waging war to enable trade..$^{70}$ They also think that Grotius was addressing Dutch merchants as a class, in order to persuade them to be more enterprising in the cause of war. Finally, the European governments at large were addressed. Grotius never published the manuscript of De Iure Praedae, except for chapter 12 on The Freedom of the Seas in 1608.

While Vitoria had devised the ideal order of a natural society between human beings, Grotius famously invented the ideal order of a physical nature free for all, or as he immortalised it, 'the freedom of the seas'.

'For today the use of the waters is common, exactly as it has been since the creation of the world. Therefore, no man has a right nor can acquire a right over the seas which would be prejudicial to their common use' ${ }^{71}$

'Nature' wrote Grotius 'founded the society' among all human beings. Wisely, nature did not 'supply every region with the necessities of life'. But the geography of nature, which includes oceans, meant that different lands were conveniently connected with each other and meteorology contributed 'by means of winds', thus facilitating 'access to every nation'. The ideal order of a free nature also helped dispel the theoretical and ethical difficulties of war. On the one hand, in the event of necessity, the private use of force or the execution of rights was just and in accordance with the

\footnotetext{
${ }^{69}$ Who, to the dismay of everyone in the Dutch provinces, almost managed to create a company in France devoted solely to peaceful trade. Both Fruin and van Ittersum mention shareholders that renounced their share of the booty or gave it to the poor. Fruin, An Unpublished Work of Hugo Grotius's 2003 (n. 67); van Ittersum, Profit and Principle 2006 (n. 40) 168.

70 van Ittersum, Profit and Principle 2006 (n. 40) 168.

${ }^{71}$ Grotius, Hugo, The Freedom of the Seas or the Right which Belongs to the Dutch to Take Part in the East Indian Trade, ed. James Brown Scott; Ralph van Deman Magoffin, trans., (New York: Oxford University Press, 1916$)$, 55.
} 
natural order'. On the other hand, nature was above and beyond religion, and therefore constituted the bottom line to justify a requital of injuries, by means of war, between Christians. The right to war became a 'sort of right of nature'. ${ }^{2}$

Together with the private right to defend rights by force if necessary, the ideal order of nature also provided two new rights well adapted to the needs of the problems faced: "the right to engage in commerce' and the right to 'enjoy access to or trade with the subjects' of any state. ${ }^{73}$ According to Martine van Ittersum, the utopian aspect of Grotius's De Iure Praedae was the sentiment, shared with Van Heemskerck, that the capture of the Santa Catarina would help to realise the natives' aspirations for freedom and protection from the Portuguese. ${ }^{74}$

Straumann argues that Grotius's original contribution was to isolate an existing tradition of natural rights with Roman law remedies and transform those remedies into a subjective moral quality of peoples, groups and individuals ${ }^{75}$ From a certain perspective that is, of course, the case. Canon and civil law were heavily influenced by Roman law during the Middle Ages. ${ }^{76}$ Grotius participated in the renewed focus on the tradition of natural rights in the international realm that Vitoria inaugurated, and naturally added more Roman law to it since he was particularly interested in developing the international theory of private conflicts. Both elements - natural rights and Roman law - are crucial aspects of Grotius's legal theory. Moreover, in order to grasp his overall political,

\footnotetext{
${ }^{72}$ Grotii, De Jure Praedae. Comentarius 2003 (n. 40) 30, 36, 83, 86. A discussion of Grotius's new secular reading of the Bible in order to justify war on the basis of nature can be found in Somos, Mark. 'Secularization in De Iure Praedae: From Bible Criticism to International Law', in Property, Piracy and Punishment: Hugo Grotius on War and Booty in De Iure Praedae - Concepts and Contexts, ed. Hans W. Blom, (Leiden, Boston: Brill, 2009), 147-191.

${ }^{73}$ Grotius, Commentary on the Law of Prize and Booty 2006 (n. 65), 183.

74 van Ittersum, 'Hugo Grotius in Context' 2003 (n. 64), 535. Apparently, during the first of the colonial and maritime Dutch-English conferences (1613), Grotius failed to convince the English party about VOC's continued interest in 'defending the natives'. Borschberg, Peter. Hugo Grotius, the Portuguese and Free Trade in the East Indies (Singapore: Nus Press, 2011), 295; Grotius, Commentary on the Law of Prize and Booty 2006 (n. 65), 256.

${ }^{75}$ Straumann, Benjamin. 'Natural Rights and Roman Law in Hugo Grotius's Theses LVL, De Iure Praedae And Defensio Capitis Quinti Maris Liberi, in Blom, Property, Piracy and Punishment 2009 (n. 72), 341-365, 351.

${ }^{76}$ Legendre, Pierre. La penetration du droit romain dans le droit canonique classique de Gratien a Innocent IV (11401254) (Paris: Jouve, 1964).
} 
moral and cultural project it is particularly important to grasp the metaphysics and epistemology of the natural rights element.

Vitoria and Grotius took upon themselves the roles of speakers to conscience. They pointed to reasons why the consciences of their audiences needed to be illuminated further. The intellectual strategy is, on the face of it, entirely intricate. However, once the mechanics are understood it seems quite simple. On the one hand, there is a claim about reason or a distant God that has decreed and made a certain ideal order, the natural society, the freedom of the sea. I use the term 'distant God' to refer to God understood as a creator, but not as a source of our knowledge in terms of practical reason..$^{77}$ Ironically, natural rights are treated in a more secular fashion in the work of Vitoria (the theologian) than is the case in that of Grotius and Locke. Of the three authors, Vitoria is the only one to have devised - in de Indis - an ideal order founded in reason, that of the 'natural society', without mentioning of God. ${ }^{78}$ But all three authors regard the function of reason and the distant God as grounding for the ideal in the same manner. With regard to Locke John Dunn writes that 'the purposes of God' dominate the 'entire intellectual construction' with 'axiomatic centrality' ${ }^{79}$ For Grotius:

'The will of God is revealed not only through oracles and supernatural portents but above all in the very design of the Creator; for it is from this last source that the law of nature is derived' ${ }^{80}$

\footnotetext{
${ }^{77}$ A recent explanation of this classic theme can be found, for instance, in Finnis, John. Natural Law and Natural Rights (Oxford: Oxford University Press, 2011), 403-410; see also Strauss, Natural Rights and History 1971 (n.1), chapter 6.

${ }^{78}$ 'The first proof comes from the law of nations (ius gentium), which either is or derives from natural law, as defined by the jurist: 'What natural reason has established among all nations is called the law of nations' (Institutions I.2.1.)', Vitoria, 'On the American Indians' 1991 (n. 42), 278.

${ }^{79}$ Dunn, John. The Political Thought of John Locke: An Historical Account of the Argument of the 'Two Treatises of Government' (Cambridge: Cambridge University Press, 1969), 12.

${ }^{80}$ Grotius, Commentary on the Law of Prize and Booty 2006 (n. 65), 21. Merio Scattola rightly noted that this is different to Lutheran, Calvinistic or Catholic (such as that of Vazquez de Menchaca), voluntarism of the sixteenth century. See Scattola, Merio. 'Law, War and Method in the Commentary on the Law of Prize by Hugo Grotius', in Blom, Property, Piracy and Punishment 2009 (n. 72), 79-103, 97.
} 
With respect to this ideal order as a design of God, Darwall has shown that in Grotius's mature work on international law, The Laws of War and Peace, what 'grounds the law is not a superior's will, but our common rational and sociable nature conceived already in juridical or "quasi-jural" terms' ${ }^{81}$ To this perspective I would add that, in an early phase, Grotius's system of natural law and natural rights involved the existence of a designer of nature who is a distant God. This distant God was removed easily, though not unproblematically, in The Laws of War and Peace. Thus, Grotius became an 'internalist' by amnesia. ${ }^{82}$ At any rate, as mentioned above, reason and the distant God operate in the same manner.

On the other hand, there is an order of necessity that must be followed, or so it appears. This is evidenced by the presence of soldiers in America and by the breach of the Portuguese monopoly, both involving violence, if necessary, as a means of attaining the ideal order. And natural rights, the number of which is increased as problems arise are the means of connecting the two orders.

The way in which Grotius addressed conscience is even more interesting than the method adopted by Vitoria. As a jurist and a Protestant he was lenient in appealing to individuals' conscience. However, this did not exclude - on the contrary, it made it more necessary - that he should make his case in a manner that sought to guide conscience, especially in a matter in respect of which he regarded the reason of the state as being encapsulated in the form of justice. In the context of the complex theological questions that arose during the Dutch War of Liberation from the Spanish oppressor, rightful punishment seems to be the thread that connects (international) politics and theology in

\footnotetext{
${ }^{81}$ Darwall, Stephen. 'Grotius at the Creation of Modern Philosophy'. Archiv für Geschichte der Philosophie 94 (2012) 296-325, 309.

${ }^{82}$ On the term 'internalist' see Darwall, 'Grotius at the Creation of Modern Philosophy' 2012 (n. 81), 314. See also the discussion by Irwin who considers Grotius as purely a scholastic and not an innovator: Irwin, Terence. The Development of Ethics: A Historical and Critical Study v. II: From Suárez to Rousseau (Oxford: Oxford University Press, 2008), 88-89.
} 
Grotius's thinking. ${ }^{83}$

One of the main concerns in De Iure Praedae appears to be that of how to reduce this type of lingering doubt about the justice of the war in the subjects' conscience, that is to say, in the minds of those actually involved in fighting in a war: 'those persons who are bound by the law of a state' ${ }^{84}$ On this issue, Grotius also followed the lead of the Spanish scholastics, especially the Salamancan theologians Vitoria and Domingo de Soto who had refuted the Dutchman Adrian Florisz (tutor and regent of the Emperor Charles V), later Pope Hadrian VI. In cases where subjects suffered from moral doubt about the legitimacy of a command, Florisz had defended that the decision of the individual subject prevailed, regardless of the consequences. Narrowing down the question to soldiers, Soto rejected this ample leeway for disobedience on the ground of the danger of dissolution of the commonwealth. ${ }^{85}$ At the outset Grotius established that often the subjects could not really know the many causes of a war, nor was 'it fitting that a private individual should be curious in such a situation' ${ }^{86}$ His conclusion was that subjects who had doubts about the justice of war waged by his lord or king nevertheless had to obey, unless the issue was a blatant crime, such as piracy. The difficulty was that 'right is based upon fact', not on 'universals', and very few could be expected to have access to the particulars of a situation. Therefore, a magistrate involved in passing judgment about the justice of the war should be trusted. If in doubt one must obey. 'One who really doubts does not understand anything' ${ }^{87}$ Grotius's conclusion was that the subject who

\footnotetext{
${ }^{83}$ Blom, Hans W. 'Grotius and Socinianism', in Socinianism and Arminianism: Antrinitarians, Calvinists and Cultural Exchange in Seventeenth-Century Europe, eds. Martin, Mulsow and Jan Rohls (Leiden: Brill, 2005) 121-147, 143. A glimpse of that complexity is offered by Grotius Hugo. Defensio Fidei Catholicae de Satisfactione Christi, Adversus Faustum Socinum Senensem, edited with an introduction and notes by Edwin Rabbie, with an English translation by Hotze Mulder (Aasen/Maastricht: Van Gorcum, 1990).

${ }^{84}$ Grotius, Commentary on the Law of Prize and Booty Grotius 2006 (n. 65), 67.

${ }^{85}$ On Florisz and Soto, see Schüßler, Moral im Zweifel 2003 (n. 63), 132-143, especially 141; on Florisz and Grotius, see also Scattola, 'Law, War and Method in the Commentary on the Law of Prizeand Booty' 2009 (n. 80), 89.

${ }^{86}$ Grotius, Commentary on the Law of Prize and Booty Grotius 2006 (n. 65), 80.

${ }^{87}$ Thus he or she cannot manage the laws of nature, in this case Law XIII, which states that if two laws cannot be simultaneously applied the highest norm prevails. Grotius, Commentary on the Law of Prize and Booty Grotius 2006 (n. 65) 77; in Latin: 'Qui vero ambiguit apprehendit nihil. Nec obstat, quod dubitas ne feceris. Non enim qui dubitat bellum
} 
did not wage war when the magistrate commanded it, and did not know that it was unjust, sinned, 'not only against civil matters, but also against his conscience'. ${ }^{88}$ Moreover, the subjects on both sides would as a rule wage a just war, again, 'provided that reason does not rebel after the probabilities have been weighed' ${ }^{89}$ The magistrates, though, would either have a right to wage war or not have such a right.

In De Iure Praedae Grotius had to modify the canonical doctrine about private war in order to defend the capture of the Santa Catarina for which the country of Holland was answerable.${ }^{90}$ In this case he refuted Pope Innocent IV as well as leading lawyers of the thirteenth and fourteenth centuries such as Hostiensis and Baldus. Anyone, Innocent IV had written, could defend him or herself and his or her things, but that was 'not properly called war, but defence'. Innocent also wrote that when it was impossible to recover one's goods and one's right, one could start a war but only with the permission of the superior authority: if that was a prince, one needed the prince's permission. That 'seemed just', Innocent added, since 'no one could licitly manage the laws (temperare iura) without the authority of the founder of laws' ${ }^{91}$ Grotius commented that 'certainly', Innocent's authority ought to 'carry little weight in cases relating to public law or to the law of nations' ${ }^{92}$ Thus, the Dutch jurist instead defended the legitimacy of a private war when no judicial redress was possible. With no superior authority in the international realm, a war could be private, and could even be paradoxically called public war. ${ }^{93}$

\footnotetext{
quod imperatur justum sit necne, statim et illud dubitat, an in dubio obediendum sit... Et hoc quidem, cum cessat ratio, seu nihil definit...Jus enim ex facto oritur. Facta autem, utpote singularia, nec per artem nec per scientiam cognoscuntur, quae sunt duntaxat universalium'. Grotii, De Jure Praedae. Comentarius 2003 (n. 40), 78.

${ }^{88}$ Grotius, Commentary on the Law of Prize and Booty Grotius 2006 (n. 65), 80.

${ }^{89}$ Grotius, Commentary on the Law of Prize and Booty Grotius 2006 (n. 65), 81.

${ }^{90}$ Fruin, An Unpublished Work of Hugo Grotius's 2003 (n. 67), 13.

${ }^{91}$ Innocent IV, Apparatus in Quinque Libros Decretalium, 13. II, c.12, n. 8.

92 And Bartolus who followed Innocent. Grotius (n. 65), 67.

${ }^{93}$ Grotius, Commentary on the Law of Prize and Booty Grotius 2006 (n. 65), 233-245.
} 
The core of De Iure Praedae was accordingly devoted to increasing the probability that the causes of a war would be just, which would soothe subjects' consciences. Moreover, for Grotius 'the just war consists in the execution of a right'. Therefore, for a just war there 'must of necessity be a right' ${ }^{94}$ Similarly to Vitoria, Grotius sought to satisfy that necessity by expounding that van Heemskerck, the United Amsterdam Company and the Dutch generally had natural rights that had been injured. I agree with Scattola's thesis that Grotius's entire system is built around the question of whether both parties in a war may be right, with two conclusions: that war is lawful and that subjects must obey. The argument here further explores how natural rights are the instruments that, in a paradoxical manner, help first to remove the issue from the realm of the conscience of an individual who could not know the facts. Next, since there had been no declaration of war by the Dutch and the States General had not yet given instructions for an offensive war, natural rights also diverged from the authority of the prince or founder of the laws placing the question in the (international) realm of nature. ${ }^{95}$

\subsection{Locke: beginning property}

Writing about politics in England in the seventeenth century could not have been an easy business, for the intellectual presence of Thomas Hobbes made it at once too easy and too difficult. John Locke (1632-1704), however, managed to become both a political theorist and philosopher and, by several worthy accounts, succeeded in writing with certain independence from Hobbes's ideas. ${ }^{96}$ 'Academic, unmarried, independent', an 'unhappy' and 'unremarkable' Oxford scholar who lived most of his life among books, Locke also experienced incredible shifts of fate. One of these was his encounter with Lord Anthony Ashley Cooper, Chancellor of the Exchequer and First Earl of

\footnotetext{
${ }^{94}$ Grotius, Commentary on the Law of Prize and Booty Grotius 2006 (n. 65); Scattola, 'Law, War and Method in the Commentary on the Law of Prizeand Booty' 2009 (n. 80), 90.

${ }^{95}$ Fruin, An Unpublished Work of Hugo Grotius's 2003 (n. 67), 12-13.

${ }^{96}$ Dunn, The Political Thought of John Locke 1969 (n. 79), chapter 7.
} 
Shaftesbury, to whom Locke became doctor and advisor. It was while living in the household of that powerful patron that he wrote the Two Treatises of Government, and apparently most of his important work. Peter Laslett has argued, quite convincingly, that the book must have been written between 1679 and the autumn of 1682 . The dates are important but controverted, in particular because Locke himself persistently sought to conceal his authorship of the work during his life. He had established himself as a philosopher with An Essay concerning Human Understanding and had, in his fifties, started to taste the success of the political and cosmopolitan path. By birth Locke was a landed proprietor and later, when he entered the social circle of Lord Ashley, an investor in the African Company, the Lustring Company and finally the Bank of England. A keen and intelligent political man, introverted but witty, well informed, and who knew his place in the world, Locke juggled his twin roles as an elite philosopher, known as a 'begetter of the Enlightenment', and as a politician, as ambiguously as Francisco de Vitoria gained his reputation as a scholar of theology and as the theologian-jurist of the Spanish Empire. ${ }^{97}$

But even if there is some scholarly debate about Locke's main reason for writing the Two Treatises, there is no doubt that one of his motives was to justify the appropriation of American land - by violent means if necessary. ${ }^{98}$ In section 9 of the Second Treatise he referred to the 'Indian'. After a short but substantial introduction he postulates a natural right to punish the invasion of one's rights

\footnotetext{
${ }^{97}$ These biographical details are mostly from Laslett, Peter. 'Introduction' to John Locke, Two Treatises of Government, (Cambridge: Cambridge University Pres, 1988), quote at 18; that the role of Locke as 'sole begetter of the Enlightenment' has 'a considerably degree of truth' in Dunn, The Political Thought of John Locke 1969 (n. 79), 5. On the collaboration of Locke and the Earl of Shatesbury for planning the settlement of Carolina see Jones, Henry. 'Property, Territory, and Colonialism: An International Legal History of Enclosure'. Legal Studies (2019) 1-17. ${ }^{98}$ See Arneil, Barbara. John Locke and America: The Defence of English Colonialism (Oxford: Oxford University Press, 1996); Armitage, David. 'John Locke: Theorist of Empire?', in Empire and Modern Political Thought, ed. Sankar Muthu, (Cambridge: Cambridge University Press, 2012), 84-111; Washburn, Wilcomb E. 'The Moral and Legal Justifications for Dispossessing the Indians', in Seventeenth-Century America: Essays in Colonial History, ed. James Morton Smith (New York: The Norton Library, 1972), 15-32. Interestingly John Dunn writes that it is possible to see Locke's intellectual life as a 'sustained inquiry into the nature of the rights which human beings as such holds against one another' Dunn John. 'Measuring Locke's Shadow', in Two Treatises of Government and A Letter Concerning Toleration, with an Introduction by Ian Shapiro (New Haven and London: Yale University Press, 2003), 257-285, 267. On this topic see in particular Simmons John A. The Lockean Theory of Rights (Princeton: Princeton University Press, 1992).
} 
founded on the law of nature. Locke admitted that that would 'seem a very strange doctrine to some Men'. But he defended it with the argument that he found no other grounds 'to punish an Alien' not subject to the commonwealth's 'Legislative Authority'.

'Those who have the Supream Power of making Laws in England, France or Holland, are to an Indian, but like the rest of the World, Men without Authority' ${ }^{99}$

Unlike Vitoria, a theologian, and Grotius, a jurist, Locke is a real philosopher and a metaphysician. His ideas are far more nuanced than those of earlier writers. Nevertheless, the English philosopher's theory embraces the fundamental elements of the sixteenth and seventeenth century pro-colonial theory of natural rights described so far. In Two Treatises of Government there is the same pattern of instructing conscience, devising an ideal order, and a utopian narrative that justifies the claim of (again) invented natural rights for political realist purposes, demanded by a contingent order. Similarly to Vitoria, rather than placing reliance on titles such as granted by the King or by God, Locke defended the claims of English settlers over American land on the basis of natural rights. This is, in fact, one of the original ideas that distinguish him from other English apologists of the colonies. ${ }^{100}$ In Locke's case the ideal order is the state of nature, one of perfect freedom and perfect equality among individuals: ${ }^{101}$

To understand Political Power right, and derive it from its Original, we must consider what State all Men are naturally in, and that is, a State of perfect Freedom to order their

\footnotetext{
${ }^{99}$ Locke, John. Two Treatises of Government (Cambridge: Cambridge University Press, 1988), section 9, 273.

100 Arneil, John Locke and America 1996 (n. 98), 19.

${ }^{101}$ John Dunn's epochal description of Locke's state of nature does not achieve a complete distinction between the ideal order and the order of necessity, but comes very close to it. This is reflected in the following statement, which offers one among several instances of a near-distinction of this kind in Dunn's work: 'Indeed it (the character of the state of nature) is precisely a jural condition of equality and freedom uncontaminated by history, the history of human wickedness. But, simply because it is in this way an ahistorical abstraction, its jural essence is never to be found in a wholly uncontaminated form within human history'. Dunn, The Political Thought of John Locke 1969 (n. 79 ), 109.
} 
Actions, and dispose of their Possessions, and Persons as they think fit within the bounds of the Law of Nature, without asking leave, or depending upon the Will of any other Man.

A State also of Equality, wherein all the Power and Jurisdiction is reciprocal, no one having more than another. ${ }^{102}$

The state of nature is governed by 'a Law of Nature'. And 'Reason' is 'that Law' ${ }^{103}$ Moreover, not unlike the case of Vitoria and Grotius, Locke's 'state of nature' is, as Dunn also notes, a scenario adopted from the international realm. ${ }^{104}$ Hence to the 'international natural society' and the 'international free nature', the 'international state of nature' is now added to the theory of natural rights. And it was in this way that through Locke's free and egalitarian state of nature the theoretical possibilities of the then emerging law of nations expanded. Locke followed most thinkers in the theological tradition and refuted the patriarchalist Robert Filmer, while disagreeing with Grotius and Pufendorf, and the commonality of everything is an important part of his equalitarian state of nature. ${ }^{105}$ Locke's commonness of goods in the state of nature famously becomes private through the natural right that every individual has to appropriate goods and land through labour. ${ }^{106}$

Though the Earth, and all inferior Creatures be common to all Men, yet every Man has a Property in his own Person. This no Body has any Right to but himself. The Labour of

\footnotetext{
${ }^{102}$ Locke, Two Treatises of Government 1988 (n. 99), § 4, 269; Dunn, The Political Thought of John Locke 1969 (n. 79), 96-119.

${ }^{103}$ Locke, Two Treatises of Government 1988 (n. 99), § 6, 271. But unlike Vitoria, and to a certain extent Grotius, in the case of the English philosopher the distant God is a very explicit giver of the ideal order, and the objective foundation of the order of creation. ${ }^{104}$ Dunn, The Political Thought of John Locke 1969 (n. 79), 106.

${ }^{105}$ Tully, James. A Discourse on Property: John Locke and His Adversaries (Cambridge: Cambridge University Press, 1980), 55-79.

${ }^{106}$ Dunn, The Political Thought of John Locke 1969 (n. 79), § 26, 286; see also the discussion in Tully, A Discourse on Property 1980 (n. 105).
} 
his Body and the work of his Hands, we may say, are properly his... For this Labour being the unquestionable Property of the Labourer, no Man but he can have a right to what that is once joined to, at least where there is enough and as good left in common for others. ${ }^{107}$

Because my labour is my right and my property, explains Locke, when I mix something that was common with my work, it becomes mine. ${ }^{108}$ Most importantly, human beings' 'title' to the world is based on 'labour'. ${ }^{109}$ James Tully notes that Locke grounded his theory of natural rights on the objective foundation of God 'the maker and man as his workmanship'. It is through labour that man also becomes the maker. Hence, '[i]f there is a natural right it must be a maker's right' ${ }^{110}$

Although Locke certainly spelt it out, arguably the principle of the maker is inherent in the concept of any natural rights as presented so far. ${ }^{111}$ I refer to the sense in which making the ideal order real belongs to the core elements of a modern theory of natural rights. It is after all the right to travel, dwell and trade that makes Vitoria's natural society real. And in Grotius's understanding it is the right to trade and have access to all commercial ports that actualises the freedom of the seas. In a similar way, the labour-generated right to private property produces landed territory from the common law in the state of nature. Remarkably, certain activities that Europeans were already undertaking overseas were labelled 'natural rights' at the dawn of the discipline of international law. Moral doubt, however, stemmed from the resistance encountered in carrying out such activities and the violence required to carry them through to conclusion.

\footnotetext{
${ }^{107}$ Locke, Two Treatises of Government 1988 (n. 99), § 27, 287-288.

108 Olivecrona, Karl. 'The Term “Property” in Locke's Two Treatises of Government'. Archiv für Rechts- und Sozialphilosophie 61 (1975), 109-115, 113.

${ }^{109}$ Locke, Two Treatises of Government 1988 (n. 99), § 26, 286; § 34, 291.

110 Tully, A Discourse on Property 1980 (n. 105), 50, 58.

${ }^{111}$ Hobbes articulated the clear precursor of this idea: 'men' as the 'Makers' of commonwealths, Hobbes, Thomas. Leviathan, the English and Latin Texts, ed. Noel Malcolm (Oxford: Clarendon Press, 2012), ch. 29, 498. For a comment see Strauss, Natural Rights and History 1971 (n. 1), 193-95.
} 
That America was 'common' is what Locke implied in his iconic opening of section 49: 'Thus in the beginning all the World was America' ${ }^{112}$ However, this is only one part of the utopian aspect of his theory of natural rights. Locke's utopia also subtly describes the Europeans' appropriation of territory in America as negligible in its extent. For the common land becomes private through personal work on it. In this respect, the common land appropriated would naturally be only as much as one man's strength allows. This is connected with another requirement of Locke's theory of appropriation through labour: that enough of what is common and of good quality remains 'for others' ${ }^{113}$ The consequence of this is that 'he that leaves as much as another can make use of, does as good as take nothing at all' ${ }^{114}$ Locke depicted the new territories overseas as immense and, what is more, impossible to be covered by modern routes for money and exchange. Why, on those premises would any European wish to take more land than he needed 'in the middle of the in-land Parts of America, where he had no hopes of Commerce with other parts of the World, to draw Money to him by the Sale of the Product?' ${ }^{115}$ In short, this was a typical case of much ado about nothing. Given the manner in which labour first began, when all the world was like America, the transformation of common property into private property could lead to 'no reason of quarrelling about Title'. ${ }^{116}$

\section{A Morality for Dividing the World: The New Ius Gentium}

The three authors studied in this article agreed in encapsulating as natural rights what was thought of as a good for everyone: natural society and partnership, the freedom of the seas and the

\footnotetext{
112 Locke, Two Treatises of Government 1988 (n. 99), § 49, 301.

113 Locke, Two Treatises of Government 1988 (n. 99), § 27, 288.

114 Locke, Two Treatises of Government 1988 (n. 99), § 33, 291.

115 Locke, Two Treatises of Government 1988 (n. 99), § 48, 301.

116 Locke, Two Treatises of Government 1988 (n. 99), § 51, 302.
} 
commonness of uncultivated land. Although in the era during which they were active that approach was convenient to the nations of each author, these new rights also introduced the notion of ideal goods in the theory of international law. These natural rights represented goods and not merely legal principles. As is apparent, they go beyond mere property. The natural society, the freedom of the seas and the commonness of the state of nature had attached to them a share of the dominion of the 'commons', the materiality of a space on earth. They offered the possibility of entering a new country and dwelling there, and the appropriation of land. The freedom of the seas was meant to provide real access to ports. This is the striking aspect of natural rights when they were incorporated into the prehistory of international law: through natural rights the new writing of the law of nations begun to divide the globe.

The sense of 'commonness' in the ideal order founded upon nature, reason, and ultimately, upon a distant God, signifies purposeful acting together as opposed to 'randomness'. Natural rights provide the means to act in accordance with the ideal order, and in the process to amend and rectify reality. Hence natural rights constitute a juridical instrument of what Arnaud Macé calls a 'paradoxical form of the common' in his study of 'The Forms of the Common in Ancient Greece'. The paradox lies in the fact that 'the common' concerns what is distributed rather than something common set aside. To continue with the same ideal orders, 'the natural society', 'the freedom of the sea' or 'the state of nature' produced a natural law of equality that is related to individuals or peoples to whom natural rights are attributed, which amount to equals shares over the 'commonness' ${ }^{117}$ In this sense, a legal theory of natural rights provides the option of thinking in terms of distribution. ${ }^{18}$ Real things that belong to the material world are objects of redistribution.

\footnotetext{
117 Macé, Arnaud and Trossell, Katharine (trans.), 'Two Forms of the Common in Ancient Greece'. Annales. Histoire, Sciences Sociales 69 (2014), 441-469, 461; Borschberg captures this idea well when he writes: 'What nature has spontaneously given to man is common to all. That includes not only physical objects, but also some of the fundamental aspects of friendly interaction'. Borschberg, Hugo Grotius, the Portuguese and Free Trade in the East Indies 2011 (n. 74), 58.

118 Macé, 'Two Forms of the Common in Ancient Greece' 2014 (n. 117), 444.
} 
What gives meaning to the concept of natural rights is contesting the actual arrangement of goods, capabilities, powers or any other thing belonging to the apportionment of the current worldly structure and making an argument in favour of a shift towards a rectification of the actual state of affairs. Natural rights are the juridical instrument that allows for the rectification of an actual state of affairs by reference to an ideal order that the theologian, the jurist and the philosopher discussed in this article devised. Therefore, the culmination of distributive and commutative theories of justice is a process by which they are blended to form a theory of natural rights. The ideal order provides the framework in which the need for (re)distribution can be understood, while natural rights become instruments of commutative justice among individuals. A metaphysical structure of the world that has integrated the principle of equality allows goods to be distributed, and natural rights offer a medium through which individuals can claim that someone owes them something. An argument of abundance buttresses, as a rule, the claim that the other is somehow deserving of rectification. In Vitoria's America, it was the abundant 'gold and silver'. ${ }^{119}$ The existence of '[s]o vast portion of the world' under the control of the Portuguese was outrageous in Grotius's view. ${ }^{120}$ And in the case of Locke, as we saw above, the immensity of the territories of America represents this aspect of abundance.

Finally, a utopian narrative usually accompanies the rectification of the contingent reality through

\footnotetext{
119 Vitoria, ‘On the American Indians’ 1991 (n. 42), 279.

120 'Finally, the Dutch undertook to investigate the East Indian regions, a plan as unquestionably just as it was obviously advantageous. For what, pray, are we to think of that attitude which I shall no longer characterize as insane greed for gain, but as envy pure and simple: the fierce insistence that so vast a portion of the world (extending along an immense coastline even from the Arabian Gulf - or rather, if we also take into account other regions, from the Strait of Gibraltar - to the utmost limits of the north and spreading out to include the islands so numerous that no man can reckon them or tell their names), should be dedicated exclusively to promoting the wealth, not to say the luxury, of a single people, while lying in great part neglected and useless, although this same territory would suffice to keep many nations engaged in commerce and supplied with sustenance?'. Grotius, Commentary on the Law of Prize and Booty Grotius 2006 (n. 65),154.
} 
natural rights, which is more than a rhetorical device in order to persuade an audience. ${ }^{121}$ Although it is that too.

What was new in the work of the founders of international law was not the justification of political and military action: that was a common theme in the work of political theorists. The novelty, rather, was that far from having recourse to realist arguments of necessity, actions were justified in legal terms (of natural law) - that of natural rights. Unlike necessity, arguments concerning natural rights do not allow the individual or the group to be subjected to praise or, more particularly, to blame. ${ }^{122}$ The reason for this is that natural rights decide the moral question in advance.

The texts that appeared during what might be termed the pre-history of international law presented here represent more than merely a specific way of framing natural rights in a scholastic context. They also brought about a modernisation, an upgrade, as it were, of both natural rights and ius gentium, into which natural rights were integrated. The identification of the newly discovered globe with nature enabled thinking about the distribution of ownership and also became a fact from which European expansion drew its moral and its political authority. ${ }^{123}$ There is little point in arguing that the 'Indians' and other non-Europeans discussed by Vitoria, Grotius and Locke had or could potentially possess a natural right to resist the actions justified by the new natural rights of the Europeans: resist trade, or dispossession of land and natural resources. As argued above, natural rights first aimed to dispossess non-Europeans and, after that, also Europeans, and sought also to

\footnotetext{
${ }^{121}$ On the 'ideal social alternatives' that utopian thinking offers, see Davis, J. C., 'Utopianism', in The Cambridge History of Political Thought 1450-1700, ed. J.H. Burns, with the assistance of Mark Goldie (Cambridge University Press, 1991), 329-44.

${ }^{122}$ Even the case of necessity in Thucydides does not often exculpate, while necessity and responsibility are not mutually exclusive notions. For a discussion of these ideas, see Hoekstra, Kinch and Mark Fisher. 'Thucydides and the Politics of Necessity', in The Oxford Handbook of Thucydides, eds. Sara Forsdyke, Edith Foster and Ryan Balot (Oxford: Oxford University Press, 2017), 374-390.

${ }^{123}$ Dan Edelstein points to the identification of nation and nature as the foundation of republicanism in Jacobin France, which I consider a further evolution of the dynamics of natural rights. Interestingly, the international was first. Edelstein, The Terror of Natural Right 2009, (n. 9).
} 
address the supposedly inefficient use of natural resources of both. The former inevitably fell prey to the exercise of natural rights in the European expansion in a more radical manner due to the unequal power relationships in play. More fundamentally, natural rights shaped the morality of dividing and distributing the spatiality and materiality of the world. It was not the goal of natural rights to facilitate resistance to that division and distribution. Perhaps this task was left as a subject for future philosophical enquiry on the basis that no need was yet felt for it, or simply the gap of knowledge was opened. Vitoria showed what was the function of natural rights to a masterly degree when he argued that the Spaniards had the same natural right to travel in America that they had in France. Or that on the grounds of charity and of nature Spaniards could not prohibit the French from trading with the Spanish kingdoms with a view to preventing them from sharing in the profits available. ${ }^{124}$ To resist natural rights in a society peopled by harmless human beings who communicated with one another was out of the question.

In that sense, it is not simply the specificities of the natural rights that the writers proposed which justified the imperial endeavours being carried out. Nor were the Spanish, Dutch or English pursuing their rights on behalf of anyone other than themselves (this is precisely the function of natural rights), and much less on behalf of the natural community. What justified European expansion was both the relative position of power of those who crafted, invoked and were able to pursue natural rights and the very nature of the new morality developed on the basis of natural rights, which was designed in such a way as to play down the significance of moral decisions founded either on justice or necessity about the particular moral issues of appropriation, conquest and war.

\section{Conclusions}

\footnotetext{
${ }^{124}$ Vitoria, 'On the American Indians' (n. 42), 278, 280.
} 
The novelty of the doctrine of natural rights in international law is that it founded a new form of morality and thereby a new form of international law. To the question of whether it was just to use violence, retain a prize or appropriate foreign goods and uncultivated land in specific situations and foreign places, Vitoria, Grotius and Locke gave a positive response, on the ground that there was an abstract natural right justifying such actions. I have argued above that this new morality was built on the premises of defining an ideal order while acting within a real order of contingency. Natural rights offered the means by which to attain this ideal. In each of the three cases presented here, a situation had been created in which serious moral doubts were entertained by both public and private citizens of European powers about the justice of the actions they were carrying out and the violence involved in doing so. Doubts revolved mainly around the justice of enslaving peoples, legally or factually, dispossessing them, and the violence expansion overseas appeared to involve. Moreover, morally conscientious citizens knew that in the international realm no independent party was available that could decide on the right direction for public policies and the private involvement that necessitated. Hence citizens needed to trust their consciences. It is not surprising that the authors discussed in this article invested effort in helping citizens to reconcile 'vigorous action and inner anxiety' ${ }^{125}$

The development of specific natural rights decided the moral case as to the justice of the war in the theories of the three men we have been considering. Natural rights provided a liberal guidance for the conscience of European citizens belonging to empires and nations engaged in a global economic and geographic expansion. The method of all three authors was to argue for the existence of natural rights, which seemed to grow in parallel with the specific moral doubts involved in given situations. ${ }^{126}$

\footnotetext{
125 This forms part of Rudolf Schüßler's comments on Jean Gerson's teaching on scruples in the fifteenth century, which 'implied a change in doctrines of moral decision-making under uncertainty'. See Schüßler, Rudolf. 'Jean Gerson, Moral Certainty and the Renaissance of Ancient Scepticism'. Renaissance Studies 23 (2009), 445-462, 450.

${ }^{126}$ See also Annabel Brett with regard to the theoretical underpinnings of commercial activity: 'In Vitoria, Soto and the subsequent Jesuit casuists, and equally in Grotius and his successors in the Protestant natural law tradition, the relationship between notions of natural rights and the legitimation in conscience of an ever-increasing range of contracts
} 
Natural rights were therefore the new means by which to generate an alternative objectivity, a different approach to the moral debate - involving new concepts and new substance - that would assist individuals in allowing their consciences to decide. The work of these three authors shows that natural rights operated as epistemic tools that provided Europeans with assurance to soothe their troubled consciences.

The effects of these new theories went well beyond the realm of private forms of counsel and morality. In the sixteenth and seventeenth centuries, alongside the instruments of natural rights, a new law of nations was created to justify the expansion of European empires. Crucially, Europeans employed natural rights to ground the need for expansion not only against the indigenous populations of future colonies but also against other Europeans - natural rights became truly universal.

Analytical study of the notions and uses of natural rights in this period shows that natural rights crossed national borders as well as divisions between Catholic and Protestants. In that sense the history of natural law is not simply a historical succession of different ways of understanding that depend on which author, nation or religion is involved. There is also a consistent attempt to produce order through natural rights within the messy business of expanding European empires and colonies.

Useful as natural rights might appear - and it should not be ruled out that they may remain helpful nowadays in terms of thinking globally about equality and distribution - they do not offer a complete answer to the moral issues at stake in international or domestic politics, as I hope I have 
shown. Natural rights externalise moral decisions by establishing at the outset that a certain result is one's right. In this respect, the processes involved in reaching individual and communal moral decisions ought to complement them.

What I have sought to suggest in this article is that in the sixteenth and seventeenth centuries natural rights were employed and developed in concrete and situated political contexts. Moreover, natural rights were capable of being understood and described. One attempt to define them could be to say that natural rights were means to decide the moral questions posed by the violent redistribution of (material) goods taken to be common by the theoreticians of the expanding European empires. Natural rights ushered in an era in the legal theory of international law that integrated previous discussions about doubtful conscience into a doctrine of the laws of war. These rights were grounded on a notion of nature that was thoroughly artificial and conventional.

All this is not intended to imply that human rights are the same as natural rights. Rather, my conclusion is that a comprehensive historical, political, and theoretical (theological, moral and philosophical) study and, in particular, an investigation of their relationship with human agency and moral conscience may render the nature of human rights less mysterious and therefore more helpful in relation to the challenges posed by contemporary global politics. 


\section{Bibliography}

Alston, Philip and Ryan Goodman. International Human Rights (Oxford: Oxford University Press, 2013).

Anghie, Anthony. Imperialism, Sovereignty and the Making of International Law (Cambridge University Press, 2004).

Armitage, David. 'John Locke: Theorist of Empire?', in Empire and Modern Political Thought, ed. Sankar Muthu, (Cambridge: Cambridge University Press, 2012).

Arneil, Barbara. John Locke and America: The Defence of English Colonialism (Oxford University Press, 1996).

Aust, Helmut Philipp. "“The System Only Dreams in Total Darkness": The Future of Human Rights in the Light of Algorithmic Authority'. German Yearbook of International Law 60 (2017), 71-90.

Besson, Samantha. 'Legal Human Rights Theory', in A Companion to Applied Philosophy, eds. Kasper LippertRasmussen, Kimberley Brownlee, and David Coady, (London: Blackwell Wiley, 2016), 328-341.

Besson, Samantha, 'Justifications', in International Human Rights Law, eds. Daniel, Moeckli, Sangeeta Shah, Sandesh Sivakumaran, and David Harris (Oxford: Oxford University Press, 2014), 34-53.

Besson, Samantha. 'International Human Rights Law and Mirrors', ESIL Reflections 7 (2018), 16 April 2018, http://www.esil-sedi.eu/node/2109, 4-5

Blom, Hans W. 'Grotius and Socinianism', in Socinianism and Arminianism: Antrinitarians, Calvinists and Cultural Exchange in Seventeenth-Century Europe, eds. Martin Mulsow and Jan Rohls (Leiden: Brill, 2005), 121-147.

Borschberg, Peter, “'De Societate Publica Cum Infidelibus”. Ein Frühwerk von Hugo Grotius', Zeitschrift der SavignyStiftung für Rechtsgeschichte 115 (1998), 355-393 
Borschberg, Peter. Hugo Grotius, the Portuguese and Free Trade in the East Indies (Singapore: Nus Press, 2011).

Brett, Annabel S. Liberty, Right and Nature: Individual Rights in Later Scholastic Thought (Cambridge: Cambridge University Press, 1997).

Brett, Annabel. 'Human Rights and the Thomist Tradition', in Revisiting the Origins of Human Rights, eds. Pamela Slotte and Miia Halme-Tuomisaari (Cambridge: Cambridge University Press, 2015), 82-101.

Carducci, Michele. 'Natura (diritti della)', in Digesto Delle Discipline Pubblicistiche, ed. Sacco, Rodolfo (Torino: Utet, 2017), 486-521.

Cavallar, Georg. 'Vitoria, Grotius, Pufendorf, Wolff and Vattel: Accomplices of European Colonialism and Exploitation of True Cosmopolitans?'. Journal of the History of International Law 10 (2008), 181-210.

Dante, Alighieri. De Monarchia, Aurelia Henry, trans. (Boston and New York: Cambridge University Press, 1904).

Dante, Alighieri. De Monarchia. The 'Oxford Text' ed. E. Moore with an 'Introduction on the Political Theory of Dante' by W. H. V. Reade, MA, (Oxford: Clarendon Press, 1916).

Darwall, Stephen. 'Grotius at the Creation of Modern Philosophy'. Archiv für Geschichte der Philosophie 94 (2012), 296-325.

Deckers, Daniel. Gerechtigkeit und Recht. Eine historische-kritische Untersuchung der Gerechtigkeitslehre des Francisco de Vitoria (1483-1546), (Freiburg: Universitätsverlag, 1991).

Donnelly, Jack and Daniel J. Whelan. International Human Rights (New York: Westview Press, 2018).

Dunn, John. The Political Thought of John Locke: An Historical Account of the Argument of the 'Two Treatises of Government' (Cambridge: Cambridge University Press, 1969)

Edelstein, Dan. 'Is There a "Modern” Natural Law Theory? Notes on the History of Human Rights'. Humanity 7 (2016), 345-364.

Edelstein, Dan. The Terror of Natural Right: Republicanism, the Cult of Nature, and the French Revolution (Chicago: University of Chicago Press, 2009).

Finnis, John. Natural Law and Natural Rights (Oxford: Oxford University Press, 2011).

Fruin, Robert. An Unpublished Work of Hugo Grotius's (translated from an essay in Dutch (1868)), in Hugonis Grotii de Jure Praedae, ed. H.C. Hamaker (Clark, New Jersey: The Lawbook Exchange, 2003).

Garcia-Salmones Rovira, Mónica. The Project of Positivism in International Law (Oxford: Oxford University Press, 2013).

García-Salmones Rovira, Mónica. 'The Disorder of Economy? The First Relectio de Indis in a Theological Perspective', in System, Order and International Law: The Early History of International Legal Thought from Machiavelli to Hegel, eds. Stefan Kadelbach, Thomas Kleinlein and Roth-Isigkeit (Oxford: Oxford University Pres, 2017), 443-463.

Gearty, Conor. 'Afterword', in Revisiting the Origins of Human Rights, eds. Pamela Slotte and Miia Halme-Tuomisaari, (Cambridge: Cambridge University Press, 2015), 381-388.

Gearty, Conor. 'Human Rights: The Necessary Quest for Foundations', in Human Rights Futures, eds. Stephen Hopgood, Jack Snyder and Leslie Vinjamuri (Cambridge: Cambridge University Press, 2017), 21-38.

González, Jaime. 'La Junta de Valladolid convocada por el Emperador', in La ética en la Conquista de América, eds. Demetrio Ramos Pérez et al (Madrid: Consejo Superior de Investigaciones Científicas, 1984), 199-228. 
Gozzi, Gustavo. Rights and Civilizations: A History and Philosophy of International Law, Filippo Valente trans. (Cambridge: Cambridge Univesity Press, 2019).

Grotius, Hugo, The Freedom of the Seas or the Right which Belongs to the Dutch to Take Part in the East Indian Trade ed. James Brown Scott; Ralph van Deman Magoffin trans., (New York: Oxford University Press, 1916).

Grotius, Hugo. Defensio Fidei Catholicae de Satisfactione Christi, Adversus Faustum Socinum Senensem Rabbie, Edwin (ed.); Hotze Mulder, trans., (Aasen/Maastricht: Van Gorcum, 1990).

Grotii, Hugonis. De Jure Praedae. Comentarius, ed. Gerard Hamaker, (The Hague: Martinum Nijhoff, 2003 (1868)).

Grotius, Hugo. The Free Sea, Translated by Richard Hakluyt with William Wellwod's Critique and Grotius's Reply, ed. David Armitage, (Indianapolis: Liberty Fund, 2004).

Grotius, Hugo. The Rights of War and Peace, ed. Richard Tuck, (Indianapolis: Liberty Fund, 2005).

Grotius, Hugo. Commentary on the Law of Prize and Booty, ed. Julia van Ittersum, (Indianapolis: Liberty Fund, 2006)

Haggenmacher, Peter. Grotius et la Doctrine de la Guerre Juste (Genève: Graduate Institute Publications, 1983).

Halme-Tuomisaari, Miia. 'Methodologically Blonde at the UN in a Tactical Quest for Inclusion'. Social Anthropology/ Anthropologie Sociale 26 (2018) 456-70.

Hobbes, Thomas. Leviathan. The English and Latin Texts, ed. Noel Malcolm, (Oxford: Clarendon Press, 2012).

Hoeflich, M. H. 'Roman and Civil Law in American Legal Education and Research Prior to 1930: A Preliminary Survey'. University of Illinois Law Review (1984), 717-737.

Hoekstra, Kinch and Mark Fisher. 'Thucydides and the Politics of Necessity', in The Oxford Handbook of Thucydides, eds. Sara Forsdyke, Edith Foster and Ryan Balot, (Oxford: Oxford University Press, 2017), 374-390.

Hoffmann, Stefan-Ludwig. 'Human Rights and History'. Past and Present, 232 (2016), 1-32.

Hohfeld, Wesley Newcomb. 'Fundamental Legal Conceptions as Applied in Judicial Reasoning'. Yale Law Journal 26 (1917), 710-770.

Hunt, Lynn. Inventing Human Rights: A History (New York and London: W.W. Norton \& Company, 2008).

Innocent IV. Apparatus in Quinque Libros Decretalium (Frankfurt am Main, 1570).

Irwin, Terence. The Development of Ethics. A Historical and Critical Study v. II: From Suárez to Rousseau (Oxford University Press, 2008).

Jones, Henry. 'Property, Territory, and Colonialism: An International Legal History of Enclosure'. Legal Studies (2019) 1-17.

Korhonen, Outi. 'Within and Beyond Interdisciplinarity in International Law and Human Rights'. European Journal of International Law 28 (2017), 625-648.

Koskenniemi, Martti. 'The Wonderful Artificiality of States'. Proceedings of the ASIL Annual Meeting 88 (1995), 2229.

Koskenniemi, Martti. 'Vitoria and Us: Thoughts on Critical Histories of International Law'. Rechtsgeschichte - Legal History 22 (2014), 119-138.

Koskenniemi, Martti, 'Human Rights, Politics and Love'. Mennesker Og Rettigheter 33 (2001), 33-45.

Koskenniemi, Martti. 'Empire and International Law: The Real Spanish Contribution'. University of Toronto Law Journal 61 (2011), 1-36. 
Koskenniemi, Martti. 'Rights, History, Critique', in Human Rights: Moral or Political?, ed. Adam Etinson (Cambridge: Cambridge University Press, 2018), 41-60.

Kriechbaum Maximiliane. Actio, Ius, und Dominium in den Rechtslehren des 13. und 14. Jahrhundert (Ebelsbach: Aktiv Druck, 1996).

Laslett, Peter. 'Introduction', to John Locke, Two Treatises of Government, (Cambridge: Cambridge University Pres, 1988).

Lauterpacht, Hersch. An International Bill of the Rights of Man (with an introduction by Philippe Sands) (Oxford: Oxford University Press, 2015).

Legendre, Pierre. La penetration du droit romain dans le droit canonique classique de Gratien a Innocent IV (11401254) (Paris: Jouve, 1964).

Locke, John. Two Treatises of Government (Cambridge: Cambridge University Press, 1988).

Loeffler, James. Rooted Cosmopolitans. Jews and Human Rights in the Twentieth Century (New Haven: Yale University Press, 2018).

Loeffler, James \& Mila Versteeg, 'Foreword: The Future of Human Rights Scholarship'. Law and Contemporary Problems 81 (2018) i-xi.

Lucena, Manuel. 'Crisis de la conciencia nacional. Las dudas de Carlos V', in La ética en la Conquista de América, eds. Demetrio Ramos Pérez et al (Madrid: Consejo Superior de Investigaciones Científicas, 1984), 163-198.

Macé, Arnaud and Katharine Trossell (trans.). 'Two Forms of the Common in Ancient Greece'. Annales. Histoire, Sciences Sociales 69 (2014), 441-469.

Malcolm, Noel. Human Rights and Political Wrongs: A New Approach to Human Rights Law (London: Policy Exchange, 2017).

Mann, Itamar. Humanity at Sea: Maritime Migration and the Foundations of International Law (Cambridge: Cambridge University Press, 2016).

Moeckli, Daniel, Sangeeta Shah, Sandesh Sivakumaran and David Harris, International Human Rights Law (Oxford: Oxford University Press, 2014).

Moyn, Samuel. The Last Utopia: Human Rights in History (Cambridge: Harvard University Press, 2012).

Moyn, Samuel. 'The Embarrassement of Human Rights'. Texas International Law Journal: The Forum 1 (2015), 1-7.

Moyn, Samuel. Not Enough: Human Rights in an Unequal World (Cambridge: Harvard University Press, 2018).

Muldoon, James. 'Medieval Canon Law and the Formation of International Law'. Zeitschrift der Savigny-Stiftung für Rechtsgeschichte. Kanonische Abteilung 81 (1995), 64-82.

Mäkinen, Virpi. Property Rights in the Late Medieval Discussions on Franciscan Poverty (Leuven: Peeters, 2001).

Oakley, Francis. Natural Law, Laws of Nature, Natural Rights: Continuity and Discontinuity in the History of Ideas (New York: Continuum, 2005).

Olivecrona, Karl. 'The Term “Property” in Locke's Two Treatises of Government'. Archiv für Rechts- und Sozialphilosophie 61 (1975), 109-115.

Orford, Anne. 'International Law and the Limits of History' in Werner, Wouter, Galán, Alexis and de Hoon, Marieke (eds.), The Law of International Lawyers: Reading Martti Koskenniemi (Cambridge: Cambridge University Press, 2015), 297-320.

Pagden, Anthony. 'Human Rights, Natural Rights and Europe’s Imperial Legacy'. Political Theory 31 (2003), 171-199. 
González, Pena and Miguel Anxo. 'La “Escuela de Salamanca”: Un intento de delimitación del concepto', in Escuela de Salamanca. Filosofía y humanismo ante el mundo modern, ed. Ángel Poncela González (Madrid: Editorial Verbum, 2015).

Pereña, Luciano. 'La Escuela de Salamanca y la Duda Indiana', in Ética en la Conquista de América, eds. Demetrio Ramos Pérez et al (Madrid: Consejo Superior de Investigaciones Científicas, 1984), 291-344.

Pereña, Luciano, 'Proyecto de Reconversión Colonial', in Escuela de Salamanca. Carta Magna de los Indios. Fuentes Constitucionales, 1534-1602, eds. Luciano Pereña and Carlos Baciero, (Madrid: Consejo Superior de Investigaciones Científicas,1988), 3-32.

Reid Jr., Charles J. 'The Canonistic Contribution to the Western Rights Tradition: An Historical Inquiry'. Boston College Law Review 33 (1991), 37-92.

Sands, Philippe. 'Introduction', in Lauterpacht, Hersch. An International Bill of the Rights of Man (2015), viii-xxvii.

Sands, Philippe. East West Street: On the Origins of Genocide and Crimes Against Humanity (London: Weidenfeld and Nicolson, 2016).

Scattola, Merio. 'Law, War and Method in the Commentary on the Law of Prize by Hugo Grotius', in Property, Piracy and Punishment: Hugo Grotius on War and Booty in De Iure Praedae - Concepts and Contexts, ed. Hans W. Blom, (Leiden, Boston: Brill, 2009), 79-103.

Brown Scott, James. The Spanish Origin of International Law: Francisco de Vitoria and His Law of Nations (Oxford: Clarendon Press,1934).

Schüßler, Rudolf. 'Jean Gerson, Moral Certainty and the Renaissance of Ancient Scepticism' Renaissance Studies 23 (2009), 445-462.

Schüßler, Rudolf. Moral im Zweifel. Die scholastische Theorie des Entscheidens unter moralischer Unsicherheit v. I (Paderborn: Mentis, 2003).

Shestack, Jerome J. 'The Philosophic Foundations of Human Rights'. Human Rights Quarterly 20 (1998) 201-34.

Smeltzer, Joshua. 'On the Use and Abuse of Francisco de Vitoria: James Brown Scott and Carl Schmitt'. Journal of the History of International Law 20 (2018), 1-29.

Straumann, Benjamin. 'Natural Rights and Roman Law in Hugo Grotius's Theses LVL, De Iure Praedae And Defensio Capitis Quinti Maris Liberi, in Property, Piracy and Punishment: Hugo Grotius on War and Booty in De Iure Praedae - Concepts and Contexts, ed. Hans W. Blom, (Leiden, Boston: Brill, 2009).

Straumann, Benjamin. Roman Law in the State of Nature: The Classical Foundation of Hugo Grotius Natural Law (Cambridge: Cambridge University Press, 2015).

Strauss, Leo. Natural Rights and History, (Chicago: University of Chicago Press, 1971).

Somos, Mark. 'Secularization in De Iure Praedae: From Bible Criticism to International Law', in Property, Piracy and Punishment: Hugo Grotius on War and Booty in De Iure Praedae - Concepts and Contexts, ed. Hans W. Blom (Leiden, Boston: Brill, 2009), 147-191.

Tasioulas, John. 'On the Nature of Human Rights', in The Philosophy of Human Rights: Contemporary Controversies, eds. Gerhard Ernst and Jan Christoph Heilinger (Berlin, Boston: De Gruyter, 2012), 17-59.

Tuck, Richard. Natural Rights Theories: Their Origin and Development (Cambridge: Cambridge University Press, 1979).

Tuck, Richard. 'Introduction' in Grotius, Hugo, The Rights of War and Peace.

Tully, James. A Discourse on Property: John Locke and His Adversaries (Cambridge: Cambridge University Press, 1980). 
Tierney, Brian. 'Historical Roots of Modern Rights: Before Locke and After'. Ave Maria Law Review 3 (2005), 23 -43. de Vitoria Franciscus. de Indis et de iure belli, ed. Ernst Nys, Ernest ; John Bate Pawley, trans., (New York, London: Oceana Publications, 1917).

de Vitoria, Francisco. 'On the American Indians', in Vitoria: Political Writings, eds. Anthony Pagden and Jeremy Lawrance, (Cambridge: Cambridge University Press, 1991).

de Vitoria, Francisco, III De justitia, q. 57-66 in Comentarios a la Secunda Secundae de Santo Tomás, ed. Vicente Beltrán de Heredia (Apartado 17: Salamanca, 1934).

van Ittersum, Martine Julia. 'Hugo Grotius in Context: Van Heemskerck's Capture of the "Santa Catarina" and Its Justification in “De Jure Praedae” (1601-1606)'. Asian Journal of Social Science 31 (2003), 511-548.

van Ittersum, Martine Julia. Profit and Principle: Hugo Grotius, Natural Rights and the Rise of Dutch Power in the East Indies (1595-1615) (Leiden, Boston: Brill, 2006).

van Ittersum, Martine Julia. 'Introduction', in Hugo Grotius Commentary on the Law of Prize and Booty (Indianapolis: Liberty Fund, 2006).

Verdross Alfred. 'Die Wertgrundlagen des Völkerrechts'. Archiv Des Völkerrechts 4 (1953) 129-39.

Villanueva Fernández, Juan Manuel. 'Erasmismo o Teología Española Del Siglo XVI?', in Cervantes y las Religiones, eds. Ruth Fine and Santiago López Navia, (Madrid: Iberoamericana, 2008), 301-326.

Virgil and West, D. (trans.), The Aeneid (London: Penguin Books, 2003).

Washburn, Wilcomb E. 'The Moral and Legal Justifications for Dispossessing the Indians', in Seventeenth-Century America. Essays in Colonial History. ed. James Morton Smith, (New York: The Norton Library, 1972), 15-32.

Wehberg Hans. 'Alfred von Verdross: Völkerrecht'. Die Friedens-Warte 37 (1937) 145-49.

Wellman, Carl. The Moral Dimension of Human Rights (Oxford University Press, 2010.

Williams Robert A Jr. The American Indian in Western Legal Thought: The Discourse of Conquest (New York: Oxford University Press, 1990).

Reports:

Creating an Enabling Legal framework for REDD+Investments in Kenya, Baker \& McKenzie \& Cambridge Center for Climate Change Mitigation Research (2014), https://www.4cmr.group.cam.ac.uk/research/projects/reddpluslawproject

Steenmans, Katrien, Jane Marriott and Rosalind Malcolm. Commodification of Waste: Legal and Theoretical Approaches to Industrial Symbiosis as Part of a Circular Economy (2017), University of Oslo. Faculty of Law, Research Paper No. 2017, 26. Available at https:/www.smart.uio.no/publications/smart-working-paper-series/ 